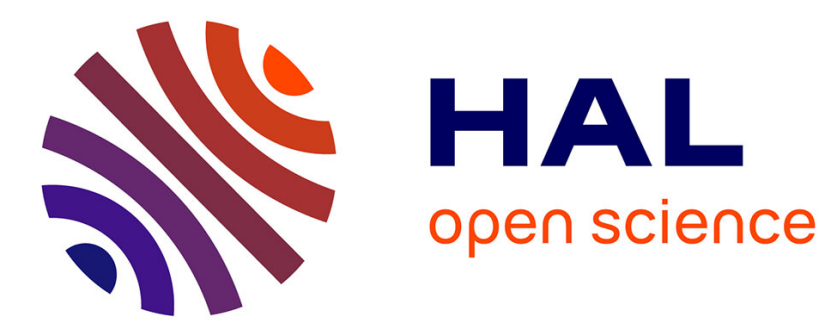

\title{
Immigration and the Future of the Welfare State in Europe
}

Alberto Alesina, Johann Harnoss, Hillel Rapoport

\section{To cite this version:}

Alberto Alesina, Johann Harnoss, Hillel Rapoport. Immigration and the Future of the Welfare State in Europe. 2018. halshs-01707760

\section{HAL Id: halshs-01707760 \\ https://shs.hal.science/halshs-01707760}

Preprint submitted on 13 Feb 2018

HAL is a multi-disciplinary open access archive for the deposit and dissemination of scientific research documents, whether they are published or not. The documents may come from teaching and research institutions in France or abroad, or from public or private research centers.
L'archive ouverte pluridisciplinaire HAL, est destinée au dépôt et à la diffusion de documents scientifiques de niveau recherche, publiés ou non, émanant des établissements d'enseignement et de recherche français ou étrangers, des laboratoires publics ou privés. 


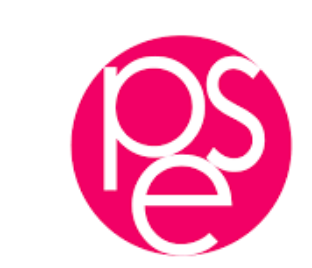

PARISSCHOOL OFECONOMICS
ECOLED'ECONOMIEDE PARIS

WORKING PAPER Nº $2018-04$

Immigration and the Future of the Welfare State in Europe

\author{
Alberto Alesina \\ Johann Harnoss \\ Hillel Rapoport
}

JEL Codes:

Keywords:
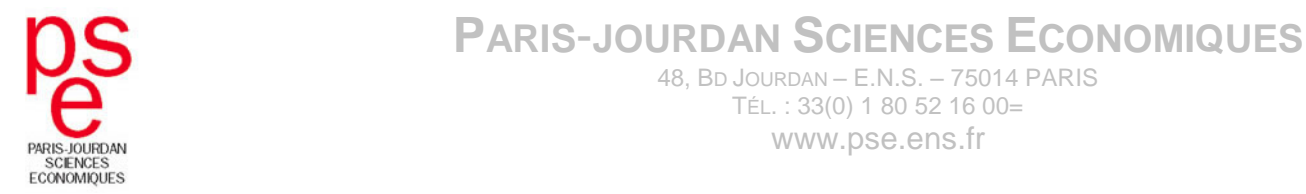


\title{
Immigration and the Future of the Welfare State in Europe*
}

\author{
Alberto Alesina ${ }^{\dagger}$ Johann Harnoss $\ddagger$ and Hillel Rapoport ${ }^{\S}$
}

December 2014 (Updated: February 2018)

\begin{abstract}
We analyze the effect of immigration on attitudes to redistribution in Europe. Using data for 28 European countries from the European Social Survey, we find that native workers lower their support for redistribution if the share of immigration in their country is high. This effect is larger for individuals who hold negative views regarding immigration but is smaller when immigrants are culturally closer to natives and come from richer origin countries. The effect also varies with native workers' and immigrants' education. In particular, more educated natives (in terms of formal education but also job-specific human capital and ocupation task skill intensity) support more redistribution if immigrants are also relatively educated. To address endogeneity concerns, we restrict identification to within country and within country-occupation variation and also instrument immigration using a gravity model.

Overall, our results show that the negative first-order effect of immigration on attitudes to redistribution is relatively small and counterbalanced among skilled natives by positive second-order effects for the quality and diversity of immigration.
\end{abstract}

\footnotetext{
${ }^{*}$ We thank Francesc Ortega and Ekaterina Zhuravskaya as well as seminar participants at the Paris School of Economics for helpful suggestions. Hillel Rapoport acknowledges support from CEPREMAP. This paper is based on Johann Harnoss' (2014) dissertation thesis "Essays on the economics of immigration and birthplace diversity", chapter 4.

${ }^{\dagger}$ Harvard University and IGIER Bocconi

¥Université Paris 1 Panthéon-Sorbonne

$\S$ Paris School of Economics, Université Paris 1 Panthéon-Sorbonne
} 


\section{Introduction}

Research on population diversity in the United States suggests that ethnic and racial diversity undermine social trust and solidarity (Putnam, 1995), which in turn negatively influence attitudes towards redistribution (Luttmer, 2001, Alesina and Glaeser, 2004). As a result, one can observe a clear negative empirical relationship in the US between ethnic diversity and redistribution, e.g. for measures such as municipal level public goods provision (Alesina, Baqir and Easterly, 1999) or welfare payments across US states (Alesina and Glaeser, 2004). Is what holds true for the United States also true for Europe?

In his influential book "Exodus", Paul Collier (2013) uses the findings from the US context to assert a similar relationship in Europe. This paper suggests that such a transposition masks important heterogeneities and is thus not necessarily valid.

For one thing, Europe and the United States differ in many respects and often stand as antipodes to one another on issues such as immigration and redistribution. The U.S. is often portrayed as a "land of opportunity" while Europe, we are told, is a "land of redistribution" (Boeri, 2010). And indeed, the US is still relatively welcoming to immigrants and averse to high levels of redistribution while Europe, in contrast, is still relatively closed to non-European immigration but relatively generous in terms of social support for anyone who has made it through its borders. The numbers reflect these differences: Europe is less diverse in terms of ethnicity ${ }^{1}$ than the United States and has a much larger welfare state. ${ }^{2}$ In terms of immigration, however, the two are converging as Europe is slowly but surely becoming a much more diverse place. Over the last decade, Europe has more than doubled - from 30 to 60 million - the number of its immigrants; as a result, most European countries exhibit rising levels of birthplace diversity, ${ }^{3}$ leading some to predict the end of the European welfare state.

This paper takes this assertion seriously and submits it to an empirical test. We show that the negative effects of ethnic/racial diversity on trust and redistribution in the context of the US cannot be simply transposed to the EU context. Instead, our results suggest that immigration (its size and skill composition) and the diversity arising from it do not necessarily translate into lower attitudinal support for redistribution. The paper belongs to the broader literature that seeks to explain social preferences based on individual level determinants. ${ }^{4}$ Median-voter models suggest that an individual's income relative to average income is a key determinant of such preferences (Meltzer and Richard, 1981). ${ }^{5}$

\footnotetext{
${ }^{1}$ The european average for ethnic fractionalization is 0.27 versus 0.49 in the United States (on a scale from 0 to 1 , based on Alesina et al., 2003).

${ }^{2}$ Public social expenditure in Europe is around $25 \%$ of GDP vs. $19 \%$ in the United States (based on 2009 data compiled at the OECD by Adema, Fron and Ladaique, 2011).

${ }^{3}$ All European OECD countries (except for four: Estonia, Greece, New Zealand, Poland and Slovakia) saw increases in the diversity of their skilled workforce between 1990 and 2000. On average, birthplace diversity increased by $17 \%$.

${ }^{4}$ See Alesina and Giuliano (2010) for a recent survey.

${ }^{5}$ Individuals with income lower than mean income will support redistribution, and redis-
} 
Age, education, occupation and past experience of unemployment are just a selection of many other factors that matter, beyond further determinants as varied as income mobility (Piketty, 1995, Benabou and Ok, 2001, Alesina and La Ferrara, 2005), risk aversion (Sinn, 1995) and beliefs about fairness (Alesina and La Ferrara, 2005). Racial differences also matter. This applies particularly to the United States, where white individuals tend to be less generous if blacks are over-represented among welfare recipients (Luttmer, 2001, Alesina and Glaeser, 2004).

Immigration affects preferences for redistribution through some of these factors. The most obvious channel, group loyalties, relates to group formation: The willingness to redistribute increases in the share of an individuals' own ethnic group in a community and decreases when other groups grow in size (this holds in particular for groups of welfare recipients). ${ }^{6}$ The degree to which such group loyalty effects are relevant in Europe is largely unclear, since group loyalty effects materialize most strongly along racial/ethnic divisions. Such racial/ethnic differences, however, are not very large in European countries. A second possible channel relates to the labor market. When immigrants enter the labor force and compete with native workers, their additional labor supply may increase native workers' perceived risk of downward income mobility. To insure against this risk, native workers likely demand more redistribution. ${ }^{7}$ A third possible channel relates to preference effects. Native citizens may derive utility from the mere presence of immigrants, or from a more diverse set of immigrants. This preference effect may be stronger for more educated native citizens due to "educated preferences" of such individuals (Hainmueller and Hiscox, 2007).

We briefly review the literature on attitudes to redistribution, with an emphasis on the recent empirical evidence for European countries. Nearly all of these focus on the size of immigration, but do not take into account immigrant diversity and the relative skill level of natives to immigrants. ${ }^{8}$ In addition, only a handful of existing studies fully address endogeneity, although immigration flows are well known to be affected by the extent of the welfare state in receiving countries (Borjas, 1999, Grogger and Hanson, 2011). Besides this issue of reverse causality, idiosyncratic differences between countries (e.g. in terms of average incomes, extent of redistribution) further complicate a purely descriptive analysis. Endogeneity is also prevalent within countries, as immigrants' select into different occupations and people's average preferences vary by the type of occupation they pursue (Guillaud, 2011). For example, immigrants sort into manually-intensive occupations where they may have comparative advan-

tribution in a society increases in the difference between the median voter's income and the mean.

${ }^{6}$ See Luttmer (2001) for early evidence on group loyalties in U.S. communities and Muñoz and Pardos (2014) for experimental results.

${ }^{7}$ Interestingly, this channel has been studied intensively in the research on attitudes to immigration (Scheve and Slaughter, 2001, Mayda, 2006, O'Rourke and Sinnott 2006, Ortega and Polavieja, 2012, among many others), but not with respect to attitudes to redistribution.

${ }^{8}$ Birthplace diversity (Harnoss, 2013) and the skill ratio (Mayda, 2006), however, are key determinants of public preferences towards immigration - and thus potentially also for attitudes to redistribution. 
tages (vis-a-vis natives), but the average native worker in these occupations irrespective of immigration - tends to favor more redistribution (since he is a net recipient of transfers).

Our empirical strategy takes these multiple issues of endogeneity into account. The standard approach would be to identify within countries or occupations and exploit solely time variation in immigration. This strategy, however, is currently constrained by the lack of high frequency occupation-level immigration data (the OECD database only includes years 2000 and 2005) and the lack of country level variation in attitudes over time. We thus follow a different approach. Our chosen identification strategy relies on variation within countries and also within occupations in a cross section of 28 countries. More specifically, we solely identify marginal effects of individual-level characteristics interacted with country/occupation-level migration variables. All other confounding country-level or occupation level variables are absorbed by fixed effects. ${ }^{9}$ This set-up allows us to avoid most endogeneity concerns. To address issues of migrant self-selection to different destinations, we also specify a gravity model of immigration to predict immigration solely on the basis of exogenous bilateral geographical variables.

We find robust evidence consistent with group loyalty and labor market effects of immigration. Native citizens' demand for income redistribution decreases by about 2 percent when the share of foreigners increases by a standard deviation (about 10 percent points in our sample). ${ }^{10}$ This effect holds on the country level, within country-occupation cells and also in an instrumental variables 2SLS model. Tellingly, group loyalty effects are stronger for natives who think that immigrants negatively affect the quality of life in natives' home countries. We also show that immigrants' socioeconomic characteristics matter, since group loyalty effects are considerably weaker when immigrants hail from culturally closer or richer origin countries. ${ }^{11}$

In addition, we find evidence consistent with labor market effects. We find that the more highly educated a native, the higher her support for redistribution - if immigrants are also mostly highly educated. An increase of the skill ratio of immigrants to natives by one standard deviation increases skilled natives' demand for redistribution by about 1 percent. These results hold also within country-occupation cells and are driven by occupations with higher exposure to immigrants. Two reasons make it unlikely this is not merely a reflection of well-known preference effects: first, attitudes to immigrants do not affect this channel (the effect holds in subsamples of natives with negative and positive views on immigrants). Second, using alternative indicators of labor market skill (a measure of job-specific human capital and two measures of task skill intensity following Peri and Sparber, 2009) yields very similar results. ${ }^{12}$

\footnotetext{
${ }^{9}$ This empirical strategy has been employed by, among others, Mayda (2006).

${ }^{10}$ In other words, a one-percentage point increase in the share of foreigners lowers natives' support for redistribution by about 0.2 percent.

${ }^{11}$ We do, however, find no robust evidence that immigration from certain countries (e.g. from Arab, Muslim or South-Saharan origins) affects peoples' attitudes.

${ }^{12}$ Finally, we find some residual preference effects: Highly educated natives want more
} 
Our paper makes three main contributions. First and foremost, we take a number of steps to address endogeneity. We focus our analysis on variation within countries and even within a country's ISCO 1-digit level occupations to exclude potential confounding effects of other variables. We also specify a gravity model of bilateral migration to address reverse causality. Second, we measure immigration as an actual outcome variable; the vast majority of previous papers uses variables of perceived (rather than actual) immigration. Third, we focus not only on the share of immigration, but analyze all key dimensions in an integrated framework: size, (birthplace) diversity and the skill ratio relative to natives - only the first of these has been analyzed in prior literature.

The rest of the paper is organized as follows: Section 2 briefly discusses the individual- and country level determinants of attitudes to redistribution and shows some descriptive correlations. Section 3 presents our data, descriptive statistics and empirical strategy; Section 4 shows results. Section 5 concludes.

\section{The demand for redistribution}

\subsection{Economic and cultural determinants}

The demand for redistribution largely depends two factors: First, if the individual thinks she benefits from an income transfer scheme and second, if she regards the other beneficiaries of the scheme to be worthy recipients of support. ${ }^{13}$

The first factor can be modeled following Meltzer and Richard (1981). Their seminal model predicts that a voter demands income redistribution if her income lies below the average. ${ }^{14}$ Benabou and Ok (2001) develop a more advanced model incorporating people's "prospect of upward mobility". Their theory explains why voters with sub-average income in fact often do not want more redistribution, since they rationally expect to lie above the average in future. This social mobility hypothesis performs much better empirically, as tested e.g. using German and U.S. data by Corneo (2001) or for the OECD by Corneo and Grüner (2002). Alternative models assume that people infer on the future through their experience of past income mobility (Piketty, 1995). Since subjective assessments of social mobility can be biased, Alesina and La Ferrara (2005) further develop objective measures of income mobility. They find that an individual's predicted probability to reach at least the 7th percentile in the U.S. income distribution clearly lowers her demand for redistribution. The degree of risk aversion also clearly affects people's demand for redistribution, which in fact acts as insurance against negative future income shocks (Sinn, 1995).

Besides these economic arguments, cultural factors matter. Older people and women are known to demand more redistribution, more educated people

redistribution if immigration is diverse. This effect varies considerably with preferences for immigration and disappears in natives with negative views on immigrants.

${ }^{13}$ For a survey of the literature, see Alesina and Giuliano (2010) and Stichnoth and Van der Straeten (2013).

${ }^{14}$ This basic model, however, has only limited empirical support (Alesina and Glaeser, 2004). 
do so much less, even conditional on income. ${ }^{15}$ Compared with atheists, religious people in the U.S. support redistribution (largely irrespective of religious affiliation, Alesina and Giuliano, 2010), but these results do not hold in experimental contexts (Fong, 2001). Besides religion, general beliefs about the poor elicit strong responses in terms of support for redistribution. Americans who believe that economic success in life depends more on own hard work rather than luck or fate are less willing to support the poor (Alesina and La Ferrara, 2005). These beliefs can be the result of indoctrination. Alesina and FuchsSchündeln (2007) use the natural experiment of German unification and show that former East-Germans, especially older age cohorts, have a relatively higher preference for state interventions and income redistribution. Such beliefs are also remarkably stable. Using data from the European Social Survey, Luttmer and Singhal (2011) show that first and even second-generation immigrants from countries with more positive general attitudes to redistribution largely maintain their preferences in their new social environments.

\subsection{Race, ethnicity, birthplace and redistribution}

Cultural beliefs correlate with race, especially in the United States. In many studies, representatives of the (white) American majority are found to be much less supportive of redistribution than members of minority groups (Alesina and La Ferrara, 2005). This is typically interpreted not only as heterogeneity in cultural preferences, but as sign of racial prejudices. Using individual data for the U.S., Luttmer (2001) shows evidence for "group loyalty effects", namely that support for redistribution increases if members of the respondent's own ethnic group are over-represented among welfare recipients. Using experimental data, Luttmer and Fong (2009) study actual self- reported attitudes as well as charitable giving in a dictator game (where respondents choose which fraction of income to allocate to a charity dedicated to Hurricane Katrina victims). The authors find no direct effect of race (of respondent or victim presented in the experiments) in the experimental setting, but do so for people who identify strongly as whites or blacks. Whites who identify strongly as such give less to victims portrayed as black, blacks who identify strongly with their own group give more. According to this research, social identity affects attitudes, but race in itself (without being a marker of identity) does not. This illustrates that redistribution does not travel racial boundaries easily. The mechanism can go through different specific channels. Besides social identity, a lower degree of altruism or a lower demand for insurance (when the poor are disproportionately minorities) can play a role.

Empirical evidence for the U.S. shows that lower attitudes to redistribution due to racial heterogeneity even extend to lower actual levels of redistribution. Alesina, Baqir and Easterly (1999) show that U.S. cities and metropolitan areas with higher racial heterogeneity provide fewer productive public goods (e.g.

\footnotetext{
${ }^{15}$ This result for education is still - to some extent - an empirical puzzle (Alesina and Giuliano, 2010).
} 
public schools). Alesina, Baqir and Hoxby (2004) demonstrate that U.S. jurisdictions form endogenously in response to a trade-off between scale benefits and costs of racial heterogeneity. Using data on welfare spending for families with dependent children, Alesina and Glaeser (2004) show that the share of AfricanAmericans in the population correlates highly negatively with maximum welfare allowances across U.S. states. These empirical studies for the U.S. have in common that they find racial, not ethnic, linguistic or birthplace differences, to be the politically salient margin with respect to attitudes and welfare spending.

Empirical evidence for other countries, like Canada or Europe, is comparatively sparse. For Canada, Soroka et al. 2006 analyze Canadian community surveys and find that a comprehensive measure of diversity (racial, ethnic and birthplace differences) correlates negatively with trust, but find only very weak evidence for attitudes to redistribution.

For Europe, Senik, Stichnoth and van der Straeten (2009) use European Social Survey data for 22 countries and find only a weakly negative link between people's perception of immigrants' presence and attitudes. This link grows stronger for people who express a dislike of immigrants and are concerned about the economic effects of immigration. Finseraas (2009) finds that people who perceive the presence of immigrants to be welfare state burden are also less open to redistribution in general. Lately, Magni-Berton (2013) finds that immigration affects attitudes not via xenophobia or group loyalties, but via labor market concerns. ${ }^{16}$ Burgoon, Koster and Egmond (2012) show that the effect of immigration on attitudes can even be positive at the occupational level. Also using European Social Survey data, Burgoon (2014) finds that the national level link between immigration and attitudes is mediated by the degree of economic integration (e.g. dependency on unemployment benefits). ${ }^{17}$

For Germany, Stichnoth (2012) tests a similar hypothesis using socioeconomic panel data for 1997 and 2002. He finds only weak evidence for a link between regional differences in terms of immigrants' employment status and attitudes to redistribution in Germany. For Sweden, Dahlberg, Edmark and Lundquist (2012) use exogenous variation in refugee placement in the late 1980s and early 1990s and find a strongly negative causal relationship between the share of (non-OECD) foreigners in Swedish municipalities and attitudes to redistribution.

Overall, we conclude that race and attitudes to redistribution seem intricately linked in the U.S., but not so much in Europe. While the evidence for Europe is generally sparse, the salient margin of diversity to affect such attitudes is more likely to be that between natives and immigrants. Preceding studies vary in terms of their approach regarding endogeneity (in terms of reverse causality and country level heterogeneity) and in terms of their coverage regarding the salient margins of diversity (studies mostly focus on the share of immigration only). Our empirical strategy aims to take both issues into account.

\footnotetext{
${ }^{16}$ All these studies use survey-based attitudes perceptions towards immigrants to infer on the effect of immigration on redistribution, not actual levels of immigration.

${ }^{17}$ To isolate country level variables, these studies assume those latent variables to be orthogonal to other covariates and rely on random intercept models.
} 


\section{Empirical strategy and data}

\subsection{Data}

We are interested in the effect of immigration on natives' demand for redistribution. The demand for redistribution is usually derived from answers to individual level surveys questions. The European Social Survey is the largest such survey and contains information on a wide range of socioeconomic and political values for individuals in 28 European countries (including Israel, Turkey and other former Soviet Republics). Data is available for six biannual survey waves starting in 2001 and has been widely used in the study of preferences (see e.g. Card, Dustmann, Preston, 2005 or Ortega and Polavieja, 2012). Our assessment of preferences to redistribution relies on answers to the statement "The government should take measures to reduce differences in income levels".

Table 1 shows answers options by country and year for our sample. The distribution of answers is clearly skewed to the right, with a mean well above the median. In all countries, a majority of individuals "agrees" or "strongly agrees" with the statement. Countries with lowest overall preference for reduction in income differences (share of population that at least "agrees") are - among others - Denmark (0.40), the Netherlands (0.56) and Great Britain (0.60). Most in favor of lower income inequality are - among others - Portugal (0.91), Spain (0.82), Italy (0.81), France (0.81) as well as Turkey (0.91) and Greece (0.90). ${ }^{18}$ This pattern serves as reminder that attitudes to redistribution are a good proxy for a country's position on many policy related questions. Descriptive statistics for all other individual socioeconomic variables we extract from ESS can be found in the appendix.

For immigration, we draw on the Database on Immigrants in OECD countries (Dumont et al., 2010) that provides immigration stocks (above age 15) for all OECD countries in 2000, disaggregated by gender, education, labor force status and occupation. We use this rich dataset to construct shares of immigration, birthplace diversity and the relative skill ratio of natives to immigrants. Refer to the appendix for details on the construction of these variables.

Table 1 also displays some features of immigration in European countries. The (unweighted) average European country had a population of 11 percent foreign-born residents. Above-average countries are - among others - Israel, Luxembourg and Switzerland, but also Estonia and Germany. Countries with fewer immigrants are many Southern and Eastern European ones. Variance in the diversity of immigrants seems mostly driven by neighboring country effects or specific immigration histories, such as the presence of Polish and Turkish immigrants in Germany or Russian-born citizens in Eastern Europe. ${ }^{19}$ All European countries attract immigrants that are, on average, less skilled than natives (with a skill ratio of immigrants to natives' level of education below one). We

\footnotetext{
${ }^{18}$ Interestingly, the Scandinavian countries mostly lie below the European average, suggesting that respondents take the prevailing level of redistribution into account.

${ }^{19}$ We take the potential endogeneity of country borders into account in our robustness checks.
} 
merge the ESS data for six waves (2001/2-2011/12) with OECD immigration data for 2000. In line with the literature on attitudes to immigration, we restrict our analysis to individuals within the labor force aged 18-64 (Ortega and Polavieja, 2012). We obtain a repeated cross section that contains data for 28 countries and 96.958 individuals.

\subsection{Descriptive analysis}

In a next step, we look at simple correlations for an indication of patterns in the data - irrespective of potential endogeneity.

Figure 1 shows bilateral correlations for immigration as well as ethnic diversity and preferences to redistribution. In 1a) we see a somewhat negative but not very robust correlation between the share of immigrants and preferences. In 1b), we find a similar relationship with birthplace diversity, which seems more robust but potentially driven by few Eastern European countries. In 1c) we see a clearly positive and quite robust link between immigrants' skill level relative to natives and preferences. The more skilled the average immigrant, the more open the society towards redistribution. ${ }^{20}$ In $1 \mathrm{~d}$ ), we see ethnic diversity (capturing not only recent immigration but deeper ethnic cleavages), which does not correlate much with attitudes at all (unlike within the United States). Needless to say, we have to remain cognizant of endogeneity since these bilateral relationships are likely to be jointly determined by others factors.

\subsection{Empirical strategy}

The literature review and the descriptive analysis suggest that the effect of migration on public attitudes may go in either direction and even may be endogenous to preferences. Our empirical strategy addresses these issues.

In a first step, we start with a standard model of redistribution policy preferences that takes into account a wide range of individual level factors. We assume that preferences for redistribution $Y_{i k t}^{*}$ of individual $i$ living in country $k$ in year $t$ can be characterized by the following model:

$$
Y_{i k t}^{*}=\alpha X_{i k t}+\beta M i g_{k} * I_{i k t}+\phi K_{k}+\varepsilon_{i k t}
$$

where $X_{i k t}^{*}$ is a vector of individual characteristics such as age, gender, educational attainment, household income, political orientation etc. ${ }^{21} \mathrm{Mig}_{k}$ is a vector of migration variables (share of immigration, birthplace diversity and relative skill ratio) that is estimated for interaction terms with individual level factors $I_{i k t}$. $I_{i k t}$ is a vector of selected individual characteristics such as EDUCATION (formal educational attainment in 5 categories going from primary to completed tertiary education), SKILL (using ISCO four-digit level variables for the skill intensity of occupations) and $N A T I V E$ (a dummy for individuals born in the country of residence). $K_{k}$ is a vector of country-year fixed

\footnotetext{
${ }^{20}$ Note that reverse causality seems unlikely here as more redistributive countries should attract more unskilled immigrants.

${ }^{21}$ The full vector of individual level control variables is based on Alesina and Giuliano (2010).
} 
effects to capture unobserved heterogeneity between country-year pairs, $\varepsilon_{i k t}$ is an error term. ${ }^{22} \alpha, \beta, \phi$ are parameters to be estimated in our empirical model. We do not estimate the base terms for $M i g_{k}$ directly since we are interested in $\alpha$ and $\beta$ estimated from within-country variation, following Mayda (2006).

We also do not observe $Y_{i k t}^{*}$ but a variable that takes values 1 to 5 increasing in support for redistribution. This variable is ordinal such that $Y_{i k t}=1$ if $Y_{i k t}^{*}$ $\leq \mu_{1}, Y_{i k t}=2$ if $\mu_{1}<Y_{i k t}^{*} \leq \mu_{2}, Y_{i k t}=3$ if $\mu_{2}<Y_{i k t}^{*} \leq \mu_{3}, Y_{i k t}=4$ if $\mu_{3}<Y_{i k t}^{*} \leq \mu_{4}$ and $Y_{i k t}=5$ if $\mu_{4}>Y_{i k t}^{*}$ where $\mu_{1}-\mu_{4}$ are unknown parameters estimated with $\alpha, \beta, \phi$. For a more intuitive interpretation of the marginal effects to be estimated, we dichotomize this ordinal variable and create a dummy $Y_{i k t}$ that takes on values of 0 if $Y_{i k t}^{*} \leq \mu_{3}$ and 1 if $Y_{i k t}^{*}>\mu_{3} \cdot{ }^{23}$ This implies that we model the probability that an individual $i$ "agrees" or "agrees strongly" with the statement "The government should take measures to reduce differences in income levels" such that

$$
P\left(Y_{i k t}=1 \mid X_{i k t}, M i g_{k}, K_{k}\right)=\Phi\left(\alpha X_{i k t}+\beta M i g_{k} * I_{i k t}+\phi K\right)
$$

where $\Phi(\cdot)$ is the cumulative distribution function of the standard normal distribution. We assume that the error terms $\varepsilon_{i k t}$ follow a standard normal distribution, but allow for intra-group correlation within countries via clustering of standard errors on that level. We then proceed to estimating the key model coefficients $\alpha$ and $\beta$.

In a second step, we modify the baseline model to exploit occupation-level variation in immigration. The extended model describes preferences for redistribution $Y_{i k o t}$ of individual $i$ working in occupation $o$ living in country $k$ at time $t$ as follows:

$$
Y_{i k o t}^{*}=\alpha X_{i k o t}+\beta M i g_{k o} * I_{i k o t}+\phi K_{k t}+\chi L_{k o}+\varepsilon_{i k o t}
$$

$X_{i k o t}$ is still the same vector of individual level characteristics. $M i g_{o k}$ is a vector of our three dimensions of immigration (size, diversity, skill) now defined for each country $k$ 's ISCO-88 occupation $(o)$ at the ISCO one-digit level. To the previous $K_{k t}$ fixed effects we now also add $L_{k o}$ country/ISCO one-digit occupation fixed effects. We thus now identify $M i g_{k o}$ solely on the basis of variation within a country's occupational cells. This model setup allows us to account for some endogeneity from omitted variables at the country and also at the ISCO one-digit occupational level.

\section{Results}

Our objective is to test for the presence of group loyalty, labor market and preference effects of immigration with respect to attitudes to redistribution.

\footnotetext{
${ }^{22}$ This term thus absorbs time persistent country level characteristics such as differences in labor market institutions (minium wage, trade union density), ethnic diversity, the unemployment rate or income.

${ }^{23}$ In a robustness check, we also estimate this model using ordered probit estimation (available upon request).
} 


\subsection{Results for native citizens vs. non-native citizens}

We first test for the presence of group loyalty effects. We interact the three dimensions of immigration (size, diversity and skill ratio) with a dummy for native citizens and expect the interaction of Mig with native to capture the marginal effect of being a native citizen in a country/occupation with high immigration. Table 2 shows results for our full sample of workers aged 18-64 who are part of the labor force. Overall, the model seems appropriately specified. The individual control variables such as gender $(1=$ male $)$, income, education show the expected negative signs, controls like age, age-squared, past/current experience of unemployment are estimated to affect attitudes to redistribution positively. ${ }^{24}$ Interestingly, the dummy for native citizens ( 1 if respondent native citizen) is positive, suggesting that native-born workers prefer - on average more redistribution than immigrants. This stands in some contrast to empirical results from the U.S. where the white majority has lower preferences for redistribution than other minorities (notably blacks). ${ }^{25}$ This difference, however, is clearly not surprising. Native workers tend to have better access to public redistribution schemes than immigrants (depending on citizenship status).

We now turn to an interpretation of the key coefficients in our model, the interactions of native and Mig variables. The interaction with the share of immigration is estimated negatively at $5 \%$ statistical significance (model 1). A one-standard deviation increase in the share of foreigners is associated with a decrease in natives' average attitudes to redistribution by close to 2 percent (based on marginal effects at the mean in the sample). ${ }^{26}$ The estimates for the interactions with Div $v_{m i g}$ and the SkillRatio are statistically insignificant from zero. This suggests that the diversity of immigrants and the skill ratio of immigrants to natives do not affect natives' attitudes on average. In models (2) and (3), we repeat our analysis using the same model but focusing in on a much more constrained source of variation. Model (2) adds ISCO one-digit occupation fixed effects for 10 broad categories of occupations. This model thus allows us to abstract from any non time varying general characteristics that uniformly affect workers within each occupation across all countries. ${ }^{27}$ Our estimate for native $* s_{f}$ remains negative and highly significant. In a third step, we further restrict the source of variation in preferences (model 3). We now identify an effect solely within country-year and country-occupation (ISCO one-digit) cells. ${ }^{28}$ Our estimate for native $* s f$ remains significant at the $1 \%$ level. Overall, the estimates are very robust across the three models, suggesting

\footnotetext{
${ }^{24}$ All of these estimates are significant at the $1 \%$ level (except for partner currently unemployed at $5 \%$ ).

${ }^{25}$ See Alesina and Glaeser (2004).

${ }^{26}$ The standard deviation of $s_{f}$ in our sample is about 10 percentage points - the drop in redistributive preferences for a 1 percentage point increase in the share of foreigners is thus about 0.2 .

${ }^{27}$ For example, the higher average education level in management and administrative occupations (ISCO-1) compared to more manufacturing-intensive occupations (e.g. ISCO-9) is accounted for by this strategy - to the extent that this effect is uniform across countries.

${ }^{28}$ Obviously, this allows us to abstract from country-specific differences in average workers' attitudes per occupation.
} 
that occupation level endogeneities do not substantially bias our basic results.

We interpret these results as first indication of group loyalty effects between natives and immigrants (Luttmer, 2001). In other words, native workers express a dislike for redistribution in the presence of higher immigration, since such immigrants tend to rely to a larger degree on the redistributive system. ${ }^{29}$ We test this interpretation by splitting our sample into workers that hold more negative and more positive view on the economic effects of immigration. Intuitively, we find that workers who tend towards the view that "immigrants make [my country] a worse place to live" are less inclined to extend the redistributive system. For this group, the magnitude of such effects increases substantially, whereas it converges to zero for those natives holding a generally more favourably view on immigration.

\subsection{Heterogeneity in education and skills}

We proceed by extending our analysis to the subsample of native citizens only. We now interact our variables of interest with indicators of individual labor market skill. In line with the previous literature (Scheve and Slaughter, 2001, Mayda, 2006, O'Rourke and Sinnot, 2006) we interpret an individual's formal education as proxy for labor market relevant skills. ${ }^{30}$ We expect our interactions of education with immigration (size, diversity, skill ratio) to capture potential labor market effects.

Table 3 shows results for our full model (including all covariates, not shown) on our full sample restricted to native citizens. The table follows the same setup as Table 2, sequentially introducing fixed effects (models 1-3) and testing for subsample heterogeneity (models 4-5). We find that although educated natives on average demand less redistribution, they want more redistribution if immigration is relatively more skilled. More precisely, the interaction of native workers' education with the skill ratio (of immigrants to natives) is positive (estimated at the $1 \%$ level). An increase in educational attainment by one category (e.g. from secondary to some tertiary education) is associated with a $1.1 \%$ higher probability to support redistribution (based on marginal effects at the sample mean). ${ }^{31}$ Very tellingly, this effect is stronger in subsamples of workers (models 4-5) who do not work in the public sector, where they tend to be shielded mostly from competition by outsiders. This association could be driven by labor market competition, but also by preference effects. Educated natives may simply hold a generally more favorable view on immigration, which also lowers they feelings of national group loyalty. We thus re-run our model using a split sample approach. We confirm the robustness of our estimates in subsamples for both natives with positive and those with negative general

\footnotetext{
${ }^{29}$ Note that in terms of magnitude, this effect is much smaller than what Dahlberg et al. (2012) have found for native citizens in Sweden.

${ }^{30}$ This is an assumption that has been challenged frequently, e.g. by Hainmueller and Hiscox (2007) and Ortega and Polavieja (2012), among many others. We later relax this assumption.

${ }^{31}$ The strength of this effect is remarkable since statistical discrimination of immigrants in labor markets would imply a relatively low degree of competition for skilled natives (Dequied and Zenou, 2013).
} 
views on immigration (models 6 and 7). Furthermore, we test if our estimate is driven primarily by highly educated workers (thus being non-linear along the distribution of skill). We find no evidence for such non-linearity. ${ }^{32}$ Both findings suggest that this effect along the distribution of skill in the native population is driven by perceived labor market competition between skilled natives and skilled immigrants. ${ }^{33}$

Besides immigrants' relative skill, the diversity of immigrants also matters: Here, simple preference effects seem likely, since the effect is driven purely by those natives who view immigration favourably (model 7), e.g. due to a preference for a diversified set of consumption amenities, see Card, Dustmann and Preston (2012).

Table 4 extends the analysis of labor market effects by replacing our measure of native worker skill, former education, by more specific measures of human capital. This strategy allows us to abstract even more clearly from potential endogenous preferences correlated with formal education. Panel 1 shows results for a measure of ISCO four-digit level occupation-specific human capital, derived from a question in the second and fifth round of the European Social Survey. This question asks people to specify how long it would take a third person to learn the skills required to perform the same job. ${ }^{34}$ Higher values indicate higher levels of specific experience and human capital. Panels 2 and 3 show results for measures of task skill intensities as popularized by Peri and Sparber (2009), among others. We follow these authors to draw upon the O*Net database that provides data on the importance of a full set detailed communicative, cognitive and manual abilities for more than 400 highly detailed occupations in the United States. ${ }^{35}$ We obtain ISCO four-digit level indicators of the importance of communication and manual skills following the definition outlined in Peri and Sparber (2009). We now use these indicators to approximate labor market relevant skills that are - to some extent - less correlated with potential other preference-forming effects of higher formal education (e.g. lower levels of ethnocentricity). ${ }^{36}$ Throughout our estimations, we obtain very similar results. Our estimates for the interaction of skill with immigrants' skill ratio remain with the expected sign and significance at the $5 \%$ level. These estimates are robust to the inclusion of occupation-level fixed effects but lose some (but not always all) significance once we further restrict our identification to countryoccupation cells. This is not surprising, since in that latter case we now identify

\footnotetext{
${ }^{32}$ In models of attitudes to immigration, higher effects for individuals with more than 12 years of education are often interpreted as "preference effects" rather than pure labor market effects (Ortega and Polavieja, 2012).

${ }^{33}$ This interpretation is further supported by the lack of significance for the interaction of share of immigrants and education (see table 3 ).

${ }^{34}$ We follow Ortega and Polavieja (2012) in linearizing the ordinal answers into years of experience.

${ }^{35}$ We follow the standard assumption in this literature that the task intensities for occupations in the United States are comparable to those in European countries. This allows us to use these indicators in our dataset.

${ }^{36}$ The correlation between educational attainment and these variables in our sample is +.28 (job specific human capital), +.44 (communication tasks) and -.41 (manual tasks).
} 
within country/ISCO-1 digit categories and use variation in natives' skills based on ISCO-4 levels (assuming all natives within an ISCO-4 digit cell have same levelof skills). This reduces all variation in natives' education substantially to variation in skills between ISCO-4 digit level occupations.

Overall, we interpret these results as further evidence for labor market effects of immigration which affect attitudes to redistribution through perceived labor market competition between skilled natives and skilled immigrants.

\subsection{Extensions and robustness}

\subsubsection{Genetic distance, income at origin and group loyalties}

We return to our results for native citizens which we interpret as suggestive of group loyalties. It seems reasonable to assume that these effects are stronger where political group identities are formed along the dividing lines between natives and immigrants (see Luttmer and Fong, 2009, on the role of identify formation). Immigrants that are - on some measures - more dissimilar to natives should thus drive such an effect.

We test this hypothesis by conducting a simulation exercise in the spirit of Desmet, Ortuño-Ortin and Wacziarg (2012) and use the methodology employed in Alesina, Harnoss and Rapoport (2013). Essentially, we augment our $s_{f}$ measure by adding group weights $d_{j k}$ and $e_{j k}$ to each bilateral share of immigrants $\left(s_{j}\right)$ from origin country $j$ to destination $k$.

$$
s_{f, \text { augmented }}=\sum_{j=1}^{J} s_{j k} * d_{j k} * e_{j k}
$$

This allows us to weight immigrants by genetic distance and income per capita at origin, using bilateral population-weighted genetic distance (Spolaore and Wacziarg, 2009 based on Alesina et. al, 2003, and Cavalli-Sforza et al., 1994) and a unilateral measure of GDP per capita (PPP) at origin (PWT 8.0, by Feenstra et al., 2013) as inputs. ${ }^{37}$ We map genetic distance and income at origin into the two group weights $d_{j k}$ and $e_{j k}$ using a logistic function

$$
d_{j k}, e_{j k}=\frac{2}{\left(1+e^{-\left(\theta * x_{j k}\right)}\right)}
$$

where $\theta$ is a parameter that ranges from -10 to +10 and $x_{j k}$ takes on standardized values of genetic distance (for $d_{j k}$ ) and GDP/capita (for $e_{j k}$ ). This function is convenient for our purpose. ${ }^{38}$ It assigns $d_{j k}$ and $e_{j k}$ values between 0 and 2 (centered on 1 for the theoretical case that all immigrant groups are equidistant to natives). $d_{j k}$ and $e_{j k}$ then act as group weights in the calculation

\footnotetext{
${ }^{37}$ We standardize these inputs for each destination country and obtain vectors of genetic distance as well as GDP at origin that range from $0(\min )$ to $1(\max )$.

${ }^{38}$ It can be centered easily on e.g. $d_{j k}=1$ for groups at average genetic proximity (income) from the natives of a given country and set to converge to two bounds 0 and 2 . In addition, by varying a single parameter $\theta$, we can vary both the slope of the function and the spread between genetically closer (poorer) and more distant (richer) groups.
} 
of $s_{f, \text { augmented }}$. Larger absolute values of $\theta$ indicate a higher degree of relative over/under-weighting. Augmented $s_{f}$ indices based on $\theta>0$ overweight groups with higher genetic distance (richer origins), those based on $\theta<0$ overweight closer groups (poorer origins). The intuition is the following: if, say, genetically more distant (richer) groups were more valuable in terms of explaining group loyalty effects, weighting these groups with $d_{j k}>1$ and correspondingly giving a lower weight of $d_{j k}<1$ to genetically closer (poorer) groups should result in an index of $s_{f}$ that has higher explanatory power in our model than its inverse index, one where we overweight closer groups.

Table 5 shows results for these weighting schemes applied jointly. The table shows the coefficients on our augmented share of immigration $\left(s_{f}\right)$ interacted with a dummy for native citizens based on model (1) in Table 2. When holding GDP/capita constant (at $\theta_{2}=0$ ), giving more weight to genetically (culturally) closer immigrants $\left(\theta_{1}<0\right)$ lowers the estimated coefficients for group loyalty effects slightly - in turn, overweighting those groups increases the coefficient (before measurement error affects the results). ${ }^{39}$ When holding genetic distance constant at $\left(\theta_{1}=0\right)$, the estimates on $s_{f} *$ native decrease as income at origin increases $\left(\theta_{2}>0\right)$.

These simulation exercise results suggest that the effect of immigration on natives' attitudes to redistribution varies somewhat with cultural distance and income at origin (a proxy for many other variables). We interpret these results as giving more weight to our interpretation of group loyalty effects for native citizens vis-a-vis immigrants. ${ }^{40}$

\subsubsection{Robustness to restricted samples}

We conduct a range of robustness checks regarding the definition of immigrants and potential outliers in our sample.

First, we re-compute our measures for Mig using country borders pre 1989 to avoid potential biases from counting indigenous people as immigrants (e.g. in the Czech Republic where Slovak inhabitants would be counted as immigrants). We thus re-run the computation of all Mig variables. Our results are fully robust to the use of such alternative definitions of origin countries. All estimates of interest remain fully robust at $1 \%$ statistical significance and retain their magnitudes, suggesting no strong prior bias from such endogenous border effects. Still, we rely on our standard measures for migration since these post Soviet or Eastern European countries tend to have split along traditional cleavages in the population, making a group distinction along these lines relevant for our analysis. ${ }^{41}$

Second, we run our basic model restricting our dataset to the first two waves (2002 and 2004) of the European Social Survey to check if our results are driven

\footnotetext{
${ }^{39}$ We follow Spolaore and Wacziarg (2009) in interpreting genetic distance as composite measure of cultural distance.

${ }^{40} \mathrm{Still}$, we are cautious not to over-emphasize these results since these differences are statistically significant from the baseline coefficient only for a subset of genetically closer and also richer immigrants.

${ }^{41}$ Results are available upon request.
} 
not by the stock of immigrants in 2000 but by later subsequent immigration that happened in the 2000s, say after the EU enlargement round that took effect in 2004. Our estimates of group loyalty effects remain robust at the $5 \%$ and $1 \%$ significance level and even - as expected - increase slightly in magnitude. ${ }^{42}$

Third, we restrict our sample to various subsets to account for potential outliers in the distribution of $M i g$ variables. Table 6 shows results. We cut our sample first by dropping the lowest $10 \%$ of observations on the share of immigrants, the diversity of immigrants and the skill ratio, and subsequently do so for the largest $10 \%$ of observations. Our results for group loyalty and labor market effects remain fully robust in the first case and lose some - but not all - significance for group loyalty effects in the second. ${ }^{43}$ Lastly, we restrict our sample to Western European countries. ${ }^{44}$ Our results remain fully robust at very comparable magnitudes and statistical significance.

\subsection{Addressing reverse causality}

Our empirical strategy so far accounts for omitted variables at the country and country/occupation level, but not for reverse causality. Reverse causality could bias our estimates if e.g. occupations with workers that tend to demand more redistribution attract more (or relatively less skilled) immigrants. We thus proceed with an instrumental variable strategy based on a gravity model of migration. Our objective is to predict $s_{f}$, Div mig and SkillRatio solely as a function of bilateral geographic and cultural factors that are exogenous to attitudes to redistribution. ${ }^{45}$ We proceed in this vein. Specifically, we use the following model to predict bilateral migration stocks. These in turn are the basis for the calculation of predicted $s_{f}$, Div $v_{m i g}$ and SkillRatio variables that serve as instruments.

$$
\begin{aligned}
m_{j k o s} & =\alpha+\beta_{1} * \text { POPULATION } N_{k o s}+\beta_{2} * D I S T A N C E_{j k} \\
& +\beta_{3} * \text { BORDER } R_{j k}+\beta_{4} * O F F . L A N G U A G E_{j k}+ \\
& +\beta_{5} * C O L O N Y_{j k}+\chi_{j}+e_{j k o s}
\end{aligned}
$$

$m_{i j k s}$ is the bilateral immigration stock from origin country $j$ to destination country $k$ in ISCO one-digit occupation level $o$ for immigrants of skill level $s$. The choice of our model determinants follows the canonical literature set-up (e.g. Mayda, 2010, Grogger and Hanson, 2011, Beine, Docquier and Schiff, 2013, Ortega and Peri, 2009 and 2014) but is purposefully limited to variables that do not directly affect attitudes, such as native population size per ISCO one-digit occupation (from Dumont et al., 2010), bilateral distance, common border, common official language, and common colonial history (all from CEPII availably

\footnotetext{
${ }^{42}$ Results are available upon request.

${ }^{43}$ This is driven more by the omission of countries with high diversity than by the omission of countries with high share of immigration.

${ }^{44}$ Precisely, we limit the sample to countries that were part of the European Union as of 1.1.2000.

${ }^{45}$ Similar gravity models have been used to predict the share of immigration (Ortega and Peri, 2014) and birthplace diversity (Alesina et al., 2014).
} 
from Head et al., 2010). We also include origin country fixed effects $\left(\chi_{j}\right)$ to account for common origin shocks to migration which influence migrants' location decision across destinations. Our instrumentation approach thus is valid to the extent that bilateral variables do not affect attitudes to redistribution within ISCO-1 occupations othan than through immigration.

We then estimate our gravity model using the PPML estimator. ${ }^{46}$ Table 7 shows results for our gravity model. As expected, all covariates affect occupation-level migration positively, with the exception of bilateral distance (as a proxy for migration costs, this term enters negatively - border contiguity picks up the main part of this effect in our model). The migration of skilled workers is less affected by distance and border contiguity (which absorbs much of the variation in distance), but facilitated by a shared language.

Table 8 shows IV results using a 2SLS estimator on our basic model using the full distribution of answer options as dependent variable. We instrument all three margins of immigration, the share, the diversity and the skill ratio of immigrants to natives within each country's ISCO one-digit level occupation. Model (1) shows our full model for group loyalty effects, where we interact our instrumented migration variables with a dummy for native citizens. The interaction with share of immigration, which we interpret as indicative of group loyalty effects, remains negative and highly significant (at $1 \%$ level). ${ }^{47}$ We also find that natives respond negatively to increased diversity of immigrants. ${ }^{48}$ Overall, the model is based on sufficiently strong instruments, the joint instrument strength clearly lies above a critical value of $\mathrm{F}>10{ }^{49}$ We now turn to our models to illustrate education/skill heterogeneities (2)-(5). We confirm our previous probit model findings for formal education and also for job specific human capital (both at 1\%). This suggests that more skilled natives respond to more skilled immigration in part by increasing their demand for redistribution. Lastly, we turn to our models with task skill intensities. Like in our probit models, the variation in ISCO four-digit level task skill variables is not sufficient to identify an effect on attitudes within the narrowly defined country-ISCO one-digit cells.

Overall, we conclude that our main results that we interpret as indicative evidence for group loyalties and labor market effects appear robust to instrumentation and are thus unlikely to be affected by ISCO one-digit occupation level reverse causality.

\footnotetext{
${ }^{46}$ The pseudo poisson maximum likelihood (PPML) estimator has been suggested by Santos Silva and Tenreyro (2006) for applications in this context since it is does not feature the bias arising from log-linearization of the gravity equation (as is the case for OLS).

${ }^{47}$ The magnitudes between OLS and IV are not directly comparable due to different dependent variables and estimators used.

${ }^{48}$ In the context of group loyalties, this may imply that more diverse immigrants tend to hail from more (and more diverse origins), which in itself tends to magnify group loyalty effects (see our preceding discussion on cultural distance).

${ }^{49}$ Here, we note that Stock and Yogo (2002) do not provide critical values for models with three instruments. Critical values for models with two instruments lie at $\mathrm{F}$ between 4 and 7 .
} 


\section{Conclusion}

We analyze the relationship between immigration and attitudes to redistribution in Europe. Empirical studies mainly for the U.S. show that racial and ethnic differences within a community lower average preferences for redistribution and lead to lower levels of public spending. ${ }^{50}$ Strikingly, empirical evidence for Europe is very limited. We hope to fill this gap. Using European Social Survey and OECD migration data for individuals in 28 European countries, we find evidence consistent with two potential channels: Group loyalty and labor market effects.

First, a 1 percentage point increase in the share of immigrants lowers natives' preferences in favor of redistribution by about 0.2 percent (up to 0.3 percent for those with negative attitudes to immigration). This suggests that the presence of immigrants directly affects natives' preferences for redistribution. While this is true, the magnitudes are significantly smaller than those measured for the United States. We also show that these group loyalty effects increase with cultural distance between immigrants and natives and decrease in origin country income per capita - consistent with an interpretation of group loyalties.

Second, we find that immigrants' relative education level affects preferences for redistribution along the distribution of natives' skill level. College-educated natives are more likely to support redistribution if immigration is also more highly educated. Highly skilled native citizens have thus a 0.1 percent higher likelihood to demand more redistribution if the skill level of immigrants increases by 1 percentage point (relative to natives). Tellingly, these results are weaker for public sector workers, robust to using indicators of self-assessed job-specific human capital and robust to potential confounding preference effects. They also hold to a large extent when using measures of communication and manual task intensity (Peri and Sparber, 2009). We interpret these findings as indicative of labor market competition effects, namely that labor market exposure to skilled immigrants and perception of labor market competition makes educated/highly skilled natives demand more redistribution. The overall effect of these two compensating effects (group loyalties and labor market competition) on redistribution policy depends on the level of education of the median voter.

We conclude that birthplace diversity - not racial/ethnic diversity - is the politically salient margin of diversity in Europe. Immigrants - unlike ethnic minorities per se - affect natives' actual and perceived labor market outcomes. As a result, attitudes to redistribution in Europe are not purely shapred by negative group loyalty effects, but also by partly compensating positive labor market effects. Overall, the magnitude of these effects is quite low - the 2008/2009 recession in Europe had much larger effects on attitudes to redistribution. ${ }^{51}$ This suggests that while immigration to Europe does affect support for the welfare state in Europe, its effect should not be overstated.

\footnotetext{
${ }^{50}$ See Alesina and La Ferrara (2005) for a literature review.

${ }^{51}$ Support for redistribution increased on average by 3 percentage points throughout Europe - about $10-15 \mathrm{x}$ of the effects we measure for a $1 \%$ point increase in immigration.
} 


\section{References}

Adema, W., P. Fron and M. Ladaique (2011), "Is the European Welfare State Really More Expensive. Indicators on Social Spending, 1980-2012 and a Manual to the OECD Social Expenditure Database (SOCX)." OECD Social, Employment and Migration Working Paper No. 124.

Alesina, A., R. Baqir and W. Easterly (1999), "Public Goods and Ethnic Divisions." Quarterly Journal of Economics, 114(4): 1243-1284.

Alesina, A., R. Baqir and C. Hoxby (2004), "Political Jurisdictions in Heterogeneous Communities." Journal of Political Economy, 112(2): 348-396.

Alesina, A., A. Devleeschauwer, W. Easterly, S. Kurlat and R. Wacziarg (2003), "Fractionalization." Journal of Economic Growth, 8(2): 155-194.

Alesina, A. and E. La Ferrara (2005), "Preferences for Redistribution in the Land of Opportunities." Journal of Public Economics, 89(5): 897-931.

Alesina, A. and N. Fuchs-Schündeln (2007), "Goodbye Lenin (or Not?): The Effect of Communism on People." American Economic Review, 97(4): 15071528.

Alesina, A. and P. Giuliano (2010), "Preferences for Redistribution." in J. Benhabib, M. Jackson and A. Bisin (eds.): Handbook of Social Economics, Vol. 1A, The Netherlands: North Holland: 93-131.

Alesina, A. and E. Glaeser (2004), "Fighting Poverty in the U.S. and Europe: A World of Difference." Oxford: Oxford University Press.

Alesina, A., J. Harnoss and H. Rapoport (2014), "Birthplace Diversity and Economic Prosperity." Journal of Economic Growth 21(2): 101-138.

Beine, M., F. Docquier and M. Schiff (2013), "Migration, Transfer of Norms and Home Country Fertility." Canadian Journal of Economics, 46(4): 14061430.

Benabou, R. and E. Ok (2001), "Social Mobility and the Demand for Redistribution: The POUM Hypothesis." Quarterly Journal of Economics, 116(2): 447-487.

Boeri, T. (2010), Immigration to the Land of Redistribution. Economica 77(308): 651-687.

Borjas, G. (1999), "Immigration and Welfare Magnets." Journal of Labor Economics, 17(4): 607-637.

Burgoon, B., F. Koster and M. van Egmond (2012), "Support for Redistribution and the Paradox of Immigration." Journal of European Social Policy, 22(3): 288-304.

Burgoon, B. (2014), "Immigration, Integration and Support for Redistribution in Europe." World Politics, 66(3): 365-405.

Card, D., C. Dustmann and I. Preston (2005), "Understanding Attitudes to Immigration: The Migration and Minority Module of the first European Social Survey." CDP Working Paper No 03/05.

Card, D., C. Dustmann and I. Preston (2012), "Immigration, Wages, and Compositional Amenities." Journal of the European Economic Association, 10(1): 78-119. 
Cavalli-Sforza, L., P. Menozzi and A. Piazza (1994), "The History and Geography of Human Genes." Princeton University Press, Princeton.

Collier, P. (2013): Exodus. Immigration and Multiculturalism in the 21st Century, Oxford: Oxford University Press.

Corneo, G. (2001), "Inequality and the State: Comparing U.S. and German Preferences." Annales d'Economie et de Statistique, 63-64: 283-296.

Corneo, G., and H. Grüner (2002), "Individual Preferences for Political Redistribution." Journal of Public Economics, 83(1), 83-107.

Dahlberg, M., K. Edmark and H. Lundqvist (2012), "Ethnic Diversity and Preferences for Redistribution." Journal of Political Economy, 120(1): 41-76.

Desmet, K., I. Ortuño-Ortín and R. Wacziarg (2012), "The Political Economy of Ethnolinguistic Cleavages." Journal of Development Economics, 97(2): 322-338.

Dequied, V. and Y. Zenou (2013), "International Migration, Imperfect Information and Brain Drain." Journal of Development Eocnomics, 101: 117-132.

Dumont, J.-P., G. Spielvogel and S. Widmaier (2010), "International Migrants in Developed, Emerging and Developing Countries: an Extended Profile." OECD Social, Employment and Migration Working Papers No. 114.

Finseraas, H. (2009), "Income Inequality and Demand for Redistribution: A Multilevel Analysis of European Public Opinion." Scandinavian Political Studies, 32(1): 94-119.

Fong, C. (2001), "Social Preferences, Self-interest and the Demand for Redistribution." Journal of Public Economics, 82(2): 225-246.

Fong, C. and E. Luttmer (2009), "What Determines Giving to Hurricane Katrina Victims? Experimental Evidence on Racial Group Loyalty." American Economic Journal: Applied Economics, 1(2): 64-87.

Grogger, J. and G. Hanson (2011), "Income Maximization and the Selection and Sorting of International Migrants." Journal of Development Economics, 95: 42-57.

Guillaud, E. (2011), "Preferences for Redistribution: An Empirical Analysis over 33 Countries." Journal of Economic Inequality, 11(1): 57-78.

Hainmueller, J. and M. Hiscox (2007), "Educated Preferences: Explaining Attitudes Toward Immigration in Europe." International Organization, 61(2): 399-442.

Harnoss, J. (2013), "Birthplace Diversity and Attitudes to Immigration." Mimeo.

Harnoss, J. (2014), "Essays on the Economics of Immigration and Birthplace Diversity", Economies and finances. Université Panthéon-Sorbonne - Paris I, 2014.

Head, K., T. Mayer and J. Ries (2010), "The Erosion of Colonial Trade Linkages after Independence." Journal of International Economics, 81(1): 1-14.

Feenstra, R., R. Inklaar and M. Timmer (2013), "The Next Generation of The Penn World Table." Available for download at www.ggdc.net/pwt.

Lazear, E. (1999), "Culture and Language." Journal of Political Economy 107(6): 95-126. 
Luttmer, E. (2001), "Group Loyalty and the Taste for Redistribution." Journal of Political Economy, 109(3): 500-528.

Luttmer, E. and M. Singhal (2011), "Culture, Context, and the Taste for Redistribution." American Economic Journal: Economic Policy, 3(1): 157-179.

Magni-Berton, R. (2013), "Immigration, Redistribution, and Universal Suffrage." Public Choice: 1-19.

Mayda, A. (2006), "Who Is Against Immigration? A Cross-country Investigation of Individual-level Attitudes toward Immigrants." Review of Economics and Statistics, 88(3): 510-530.

Mayda, A. (2010), "International Migration: A Panel Data Analysis of the Determinants of Bilateral Flows." Journal of Population Economics, 23(4): 1249-1274.

Meltzer, A. and S. Richard (1981), "A Rational Theory of the Size of Government." Journal of Political Economy, 89(5): 914-927.

Muñoz, J. and S. Pardos (2017), "Immigration and Support for the Welfare State: An Experimental Comparison of Universal and Means-Tested Policies." Political Science Research and Methods: 1-19.

O'Rourke, K. and R. Sinnott (2006), "The determinants of individual attitudes towards immigration." European Journal of Political Economy, 22(4): 838-861.

Ortega, F. and G. Peri (2009), "The Causes and Effects of International Migrations: Evidence from OECD countries 1980-2005." NBER Working Paper 14833 .

Ortega, F. and G. Peri (2014), "Openness and Income: The Roles of Trade and Migration." Journal of International Economics 92(2): 231-251.

Ortega, F. and J. Polavieja (2012), "Labor Market Exposure as Determinant of Attitudes toward Immigration." Labour Economics, 19(3): 298-311.

Peri, G. and C. Sparber (2009), "Task Specialization, Immigration, and Wages." American Economic Journal: Applied Economics, 1(3): 135-69.

Piketty, T. (1995), "Social Mobility and Redistributive Politics." Quarterly Journal of Economics, 110(3): 551-584.

Putnam, R. (1995), "Bowling Alone: America's Declining Social Capital." Journal of Democracy, 6(1): 65-78.

Santos Silva, J. and S. Tenreyro (2006), "The Log of Gravity." The Review of Economics and Statistics, 88(4): 641-658.

Scheve, K. and M. Slaughter (2001), "Labor Market Competition and Individual Preferences Over Immigration Policy." Review of Economics and Statistics, 83(1): 133-145.

Senik, C., H. Stichnoth and K. Van der Straeten (2009), "Immigration and Natives' Attitudes towards the Welfare State: Evidence from the European Social Survey." Social Indicators Research, 91(3): 345-370.

Sinn, H.-W. (1995), "A Theory of the Welfare State." Scandinavian Journal of Economics, 95(4): 495-526.

Sorkoa, S., Johnston, R. and K. Banting (2006), "Ties that Bind: Social Cohesion and Diversity in Canada." In K. Banting, T. Courchene and F. Seidle, 
eds., The Art of the State III: Belonging? Diversity, Recognition and Shared Citizenship in Canada. Montreal: Institute for Research in Public Policy.

Spolaore, E. and R. Wacziarg (2009), "The Diffusion of Development." Quarterly Journal of Economics, 124(2): 469-529.

Stichnoth, H. (2012), "Does Immigration Weaken Natives' Support for the Unemployed? Evidence from Germany." Public Choice, 151(3/4): 631-654.

Stichnoth, H. and K. Van der Straeten (2013), "Ethnic Diversity, Public Spending and Individual Support for the Welfare State: A Review of the Empirical Literature." Journal of Economic Surveys, 27: 364-389.

Stock, J. and M. Yogo (2002), "Testing for Weak Instruments in Linear IV Regression." In Donald Andrews and James H. Stock, eds. Identification and Inference for Econometric Models: Essays in Honor of Thomas Rothenberg, New York, NY: Cambridge University Press.

\section{Appendix}

\subsection{Construction of immigration variables}

Using the DIOC-E 2000 (release 3.0) dataset provided by the OECD (Dumont, Spielvogel and Widmaier, 2010), we calculate three immigration variables (share, diversity and relative skill ratio) on two levels of aggregation, the country of destination and the ISCO 88 one-digit level occupation.

These standard literature variables allows us to characterizing the size $s_{f}$, origin-mix Div ${ }_{M i g}$, and relative skill ratio SkillRatio of the foreign-born population per country ${ }_{k}$ (or country-occupation cell $k_{k o}$ ), where $s_{j}$ is the share of immigrants of origin $\mathrm{j}$ in terms of all immigrants:

$$
\begin{aligned}
& S_{f, s k}=\left(\frac{\text { immigrants }_{s k}}{\text { immigrants }_{s k}+\text { natives }_{s k}}\right) \\
& D i v_{s k}=\sum_{j=1}^{J}\left[s_{j} *\left(1-s_{j}\right)\right]
\end{aligned}
$$

Alesina et. al. 2013 decompose the standard Herfindahl index of population birthplace diversity and show that these two variables can be interpreted as the size $\left(s_{f}\right)$ and variety $\left(\right.$ Div $\left._{M i g}\right)$ margins of birthplace diversity. The relative skill ratio of immigrants to natives follows Mayda (2006) and is defined as the $\log$ of the ratio of the share of skilled to unskilled immigrants over the ratio of the share of skilled (index $s=s$ ) to unskilled (index $s=u$ ) natives (e.g., at SkillRatio $_{k t}=1$, both populations have the same level of education).

$$
\text { SkillRatio }_{k}=\ln \left(\frac{\frac{\text { immigrant }_{s k}}{\text { immigrants }_{u, k}}}{\frac{\text { natives }_{s k}}{\text { natives }_{u k}}}\right)
$$

The input data is based on country-level census and (for some countries) additional survey data. The data covers 32 OECD destination countries and 
immigrants from all OECD origins as well as 68 further non OECD-countries of origin. Population is defined as age 15 and above, immigrants are defined as residents who are not born in their respective country of residence.

While the overall dataset is very rich, some observations suffer from missing information. The calculation of our immigration variables is mostly affected by lack of information on the country of origin. This applies only to few observations, mainly limited to Germany and Slovenia. We decide to disregard these observations since an arbitrary classification as native or foreign yields unrealistic results. Missing data on educational attainment are less problematic and relate mostly to the relative skill ratio. We keep these observations (where we don't make use of this dimension) for $s_{f}$ and Div $v_{M i g}$ but consequently drop them when calculating SkillRatio. A last issue relates to people with origins that are clearly foreign but cannot be assigned to a country of birth. The DIOC database assigns these to regions or, if impossible, to a last bucket "other origins". This issue relates mostly to the measure of immigrant birthplace diversity and mostly adds white noise. We keep thus keep these observations in the dataset.

For occupation level data, we further standardize the occupational classification to ISCO 88 for countries where national classifications are used (only Turkey in our case) and aggregate data by the one-digit level. We drop observations with missing occupational status information. in line with the ISCO classification system, we keep members of the Armed Forces separate from other occupational categories.

We thus end up with three variables (share, diversity and relative skill ratio) per country and per country/one-digit ISCO occupation combination for the year 2000 . 
Figure 1: Descriptive analysis

Dependent variable: Support for redistribution (scale 1-5), country averages

a) Share of immigrants

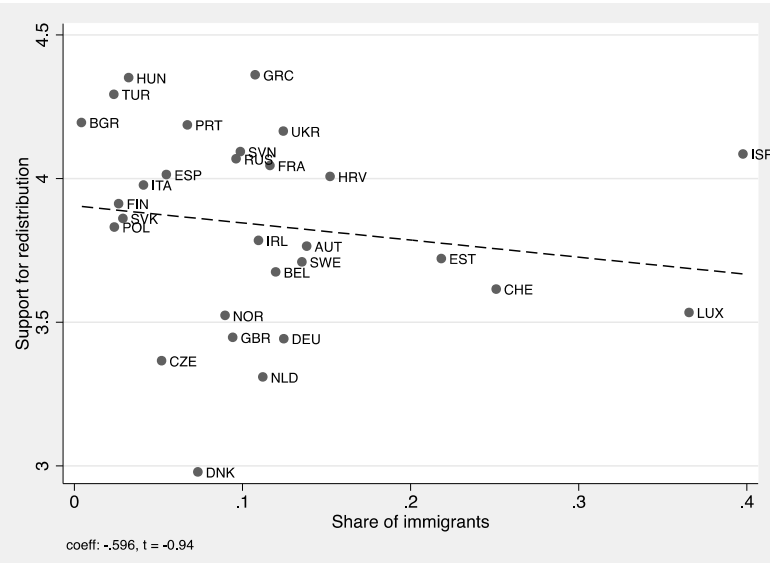

c) Relative skill ratio (immigrants/natives)

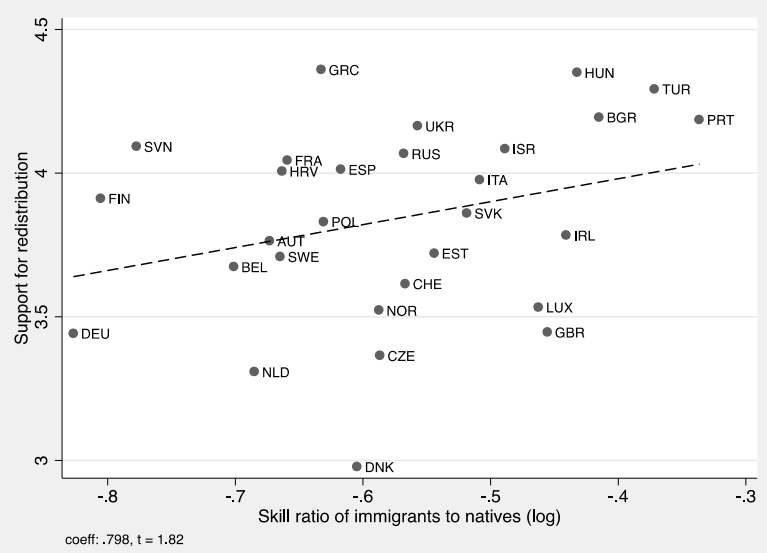

b) Diversity of immigrants

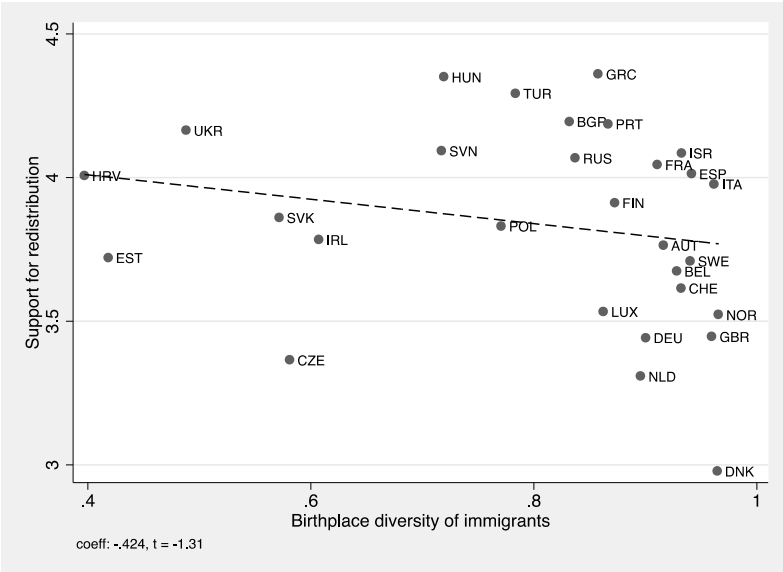

d) Ethnic diversity

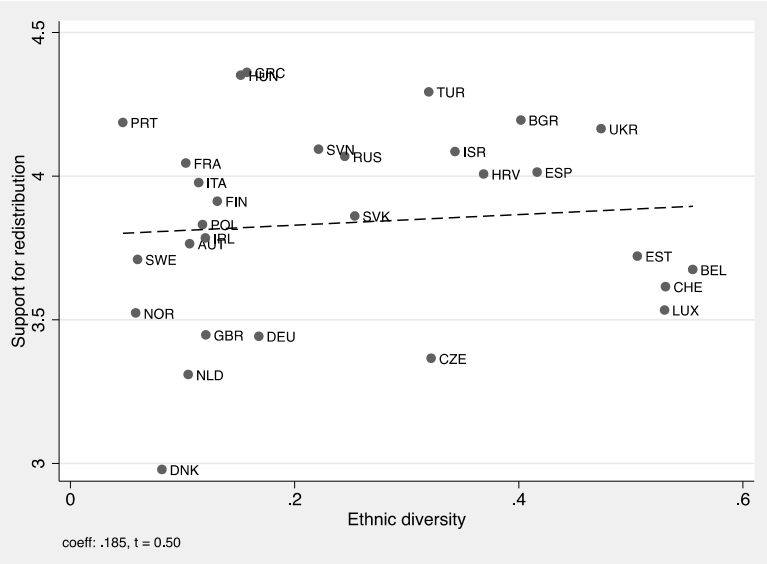


Table 1: Dependent variables

\begin{tabular}{|c|c|c|c|c|c|c|}
\hline \multicolumn{7}{|c|}{ "The government should take measures to reduce differences in income levels" } \\
\hline & 1 & 2 & 3 & 4 & 5 & Dummy \\
\hline & $\begin{array}{c}\text { Disagree } \\
\text { strongly }\end{array}$ & Disagree & $\begin{array}{c}\text { Neither agree } \\
\text { nor disagree }\end{array}$ & Agree & Agree strongly & If 4 or 5 \\
\hline FULL SAMPLE (all waves) & 0,03 & 0,13 & 0,14 & 0,42 & 0,28 & 0,70 \\
\hline \multicolumn{7}{|l|}{ BY YEAR } \\
\hline Wave 1: 2001/2002 & 0,03 & 0,15 & 0,12 & 0,46 & 0,23 & 0,69 \\
\hline Wave 2: 2004/2004 & 0,03 & 0,14 & 0,14 & 0,43 & 0,26 & 0,69 \\
\hline Wave 3: 2005/2006 & 0,03 & 0,13 & 0,15 & 0,42 & 0,27 & 0,69 \\
\hline Wave 4: 2007/2008 & 0,03 & 0,12 & 0,15 & 0,41 & 0,29 & 0,70 \\
\hline Wave 5: 2009/2010 & 0,02 & 0,11 & 0,13 & 0,39 & 0,34 & 0,73 \\
\hline Wave 6: 2011/2012 & 0,02 & 0,11 & 0,15 & 0,40 & 0,32 & 0,72 \\
\hline
\end{tabular}


"The government should take measures to reduce differences in income levels"

\begin{tabular}{|c|c|c|c|c|c|c|}
\hline & $\begin{array}{c}1 \\
\text { Disagree } \\
\text { strongly }\end{array}$ & $\begin{array}{c}2 \\
\text { Disagree }\end{array}$ & $\begin{array}{c}3 \\
\text { Neither agree } \\
\text { nor disagree } \\
\end{array}$ & $\begin{array}{c}4 \\
\text { Agree }\end{array}$ & $\begin{array}{c}5 \\
\text { Agree strongly }\end{array}$ & $\begin{array}{l}\text { Dummy } \\
\text { If } 4 \text { or } 5\end{array}$ \\
\hline SAMPLE AVERAGE & 0,03 & 0,13 & 0,14 & 0,42 & 0,28 & 0,70 \\
\hline \multicolumn{7}{|l|}{ BY COUNTRY } \\
\hline AUT & 0,03 & 0,12 & 0,16 & 0,41 & 0,28 & 0,69 \\
\hline BEL & 0,03 & 0,14 & 0,14 & 0,44 & 0,25 & 0,70 \\
\hline BGR & 0,03 & 0,03 & 0,08 & 0,33 & 0,53 & 0,86 \\
\hline $\mathrm{CHE}$ & 0,03 & 0,16 & 0,14 & 0,47 & 0,21 & 0,67 \\
\hline CZE & 0,07 & 0,15 & 0,18 & 0,33 & 0,27 & 0,60 \\
\hline $\mathrm{DEU}$ & 0,03 & 0,18 & 0,16 & 0,44 & 0,19 & 0,63 \\
\hline DNK & 0,08 & 0,31 & 0,20 & 0,31 & 0,10 & 0,40 \\
\hline ESP & 0,01 & 0,06 & 0,11 & 0,49 & 0,33 & 0,82 \\
\hline EST & 0,01 & 0,09 & 0,13 & 0,47 & 0,30 & 0,77 \\
\hline FIN & 0,02 & 0,09 & 0,15 & 0,41 & 0,34 & 0,74 \\
\hline FRA & 0,03 & 0,07 & 0,09 & 0,37 & 0,44 & 0,81 \\
\hline GBR & 0,03 & 0,18 & 0,19 & 0,45 & 0,15 & 0,60 \\
\hline GRC & 0,01 & 0,03 & 0,06 & 0,39 & 0,51 & 0,90 \\
\hline HRV & 0,01 & 0,06 & 0,11 & 0,53 & 0,29 & 0,82 \\
\hline HUN & 0,01 & 0,05 & 0,08 & 0,34 & 0,53 & 0,86 \\
\hline IRL & 0,02 & 0,12 & 0,12 & 0,51 & 0,24 & 0,74 \\
\hline ISR & 0,01 & 0,07 & 0,11 & 0,35 & 0,46 & 0,81 \\
\hline ITA & 0,02 & 0,06 & 0,11 & 0,49 & 0,33 & 0,81 \\
\hline LUX & 0,06 & 0,17 & 0,13 & 0,42 & 0,22 & 0,64 \\
\hline NLD & 0,03 & 0,23 & 0,17 & 0,42 & 0,14 & 0,56 \\
\hline POL & 0,02 & 0,10 & 0,09 & 0,46 & 0,32 & 0,79 \\
\hline PRT & 0,01 & 0,03 & 0,06 & 0,50 & 0,41 & 0,91 \\
\hline RUS & 0,01 & 0,06 & 0,16 & 0,34 & 0,43 & 0,77 \\
\hline SVK & 0,01 & 0,08 & 0,13 & 0,43 & 0,35 & 0,78 \\
\hline SVN & 0,01 & 0,06 & 0,08 & 0,44 & 0,41 & 0,85 \\
\hline SWE & 0,01 & 0,11 & 0,20 & 0,49 & 0,19 & 0,67 \\
\hline TUR & 0,01 & 0,03 & 0,04 & 0,43 & 0,48 & 0,91 \\
\hline UKR & 0,03 & 0,04 & 0,14 & 0,26 & 0,51 & 0,78 \\
\hline
\end{tabular}


Table 2: Preferences for redistribution - native citizens

Table 2: Preferences for redistribution - native citizens

\begin{tabular}{|c|c|c|c|c|c|}
\hline \multirow{3}{*}{$\begin{array}{l}\text { Dependent variable } \\
\text { Sample }\end{array}$} & \multicolumn{5}{|c|}{ Preference for Reduction of Income Differences ( $1=$ "agree" or "agree strongly") } \\
\hline & \multicolumn{3}{|c|}{ Full sample } & \multicolumn{2}{|c|}{ Perception of immigration } \\
\hline & $(1)$ & $(2)$ & (3) & $\begin{array}{c}\text { negative } \\
(4)\end{array}$ & $\begin{array}{c}\text { positive } \\
(5)\end{array}$ \\
\hline Share of immigration $*$ native citizen & $\begin{array}{c}-0.0628 * * \\
(0.0264)\end{array}$ & $\begin{array}{c}-0.0630 * * \\
(0.0264)\end{array}$ & $\begin{array}{c}-0.0620 * * * \\
(0.0195)\end{array}$ & $\begin{array}{c}-0.106 * * * \\
(0.0244)\end{array}$ & $\begin{array}{l}-0.0363 \\
(0.0225)\end{array}$ \\
\hline Birthplace diversity (immigrants) $*$ native citizen & $\begin{array}{l}-0.0147 \\
(0.0557)\end{array}$ & $\begin{array}{l}-0.0233 \\
(0.0556)\end{array}$ & $\begin{array}{l}-0.0241 \\
(0.0458)\end{array}$ & $\begin{array}{l}-0.0426 \\
(0.0671)\end{array}$ & $\begin{array}{l}-0.0214 \\
(0.0511)\end{array}$ \\
\hline Skill ratio $*$ native citizen & $\begin{array}{l}-0.0265 \\
(0.0406)\end{array}$ & $\begin{array}{l}-0.0283 \\
(0.0416)\end{array}$ & $\begin{array}{c}0.0292 \\
(0.0375)\end{array}$ & $\begin{array}{c}0.0203 \\
(0.0404)\end{array}$ & $\begin{array}{c}0.0221 \\
(0.0545)\end{array}$ \\
\hline Native citizen & $\begin{array}{c}0.0746 * * \\
(0.0380)\end{array}$ & $\begin{array}{l}0.0919 * * \\
(0.0375)\end{array}$ & $\begin{array}{l}0.0941^{* *} \\
(0.0406)\end{array}$ & $\begin{array}{l}0.209 * * * \\
(0.0640)\end{array}$ & $\begin{array}{c}0.0328 \\
(0.0415)\end{array}$ \\
\hline Income (deciles) & $\begin{array}{c}-0.0499 * * * \\
(0.00648)\end{array}$ & $\begin{array}{c}-0.0425^{* * *} \\
(0.00599)\end{array}$ & $\begin{array}{c}-0.0420^{* * *} \\
(0.00588)\end{array}$ & $\begin{array}{c}-0.0429 * * * \\
(0.00691)\end{array}$ & $\begin{array}{c}-0.0413 * * * \\
(0.00652)\end{array}$ \\
\hline Formal education (attainment levels) & $\begin{array}{c}-0.101^{* * *} \\
(0.0130)\end{array}$ & $\begin{array}{c}-0.0605^{* * *} \\
(0.0101)\end{array}$ & $\begin{array}{c}-0.0650^{* * *} \\
(0.00920)\end{array}$ & $\begin{array}{c}-0.0712^{* * *} \\
(0.00889)\end{array}$ & $\begin{array}{c}-0.0619 * * * \\
(0.0145)\end{array}$ \\
\hline Fixed effects & & & & & \\
\hline $\begin{array}{l}\text { Country-Year } \\
\text { Occupation (ISCO level-1) }\end{array}$ & $\mathrm{x}$ & $\begin{array}{l}\mathrm{x} \\
\mathrm{x}\end{array}$ & $\mathrm{x}$ & $\mathrm{x}$ & $\mathrm{x}$ \\
\hline Country-Occupation (ISCO level-1) & & & $\mathrm{x}$ & $\mathrm{x}$ & $\mathrm{x}$ \\
\hline Observations & 96,925 & 96,925 & 96,853 & 59,047 & 37,659 \\
\hline Pseudo R2 & 0.109 & 0.113 & 0.119 & 0.127 & 0.116 \\
\hline
\end{tabular}

Share, diversity and skill ratio $(\log )$ standardized with zero mean and standard deviation of 1 . Controls include: age, age squared, gender, political orientation, rural area, partner currently unemployed, ever unemployed, self-employed, household size, trade union membership and legal marital status. Standard errors corrected for heteroskedasticity and clustering of the residuals at the country level. ***, **, * indicate statistical significance at the $1 \%, 5 \%$ and $10 \%$ level, respectively. 


\section{Table 3: Preferences for redistribution - labor market skill (formal education)}

Table 3: Preferences for redistribution - heterogeneity in formal education

\begin{tabular}{|c|c|c|c|c|c|c|c|c|c|}
\hline Dependent variable & & ference for & r Redu & of Incom & ne Differer & ces $(1=$ "ag & gree" or "a & ree strong & ly") \\
\hline Sample & & Full sample & & Indu & ustry & $\begin{array}{l}\text { Percpt } \\
\text { immig }\end{array}$ & $\begin{array}{l}\text { tion of } \\
\text { gration }\end{array}$ & $\begin{array}{l}\text { Non- } \\
\text { educ }\end{array}$ & $\begin{array}{l}\text {-linear } \\
\text { ation }\end{array}$ \\
\hline Model & $(1)$ & $(2)$ & (3) & $\begin{array}{c}\text { Public } \\
\text { (4) }\end{array}$ & $\begin{array}{c}\text { Non- } \\
\text { Puhlir } \\
\text { (5) }\end{array}$ & $\begin{array}{c}\text { Negative } \\
\text { (6) }\end{array}$ & $\begin{array}{c}\text { Positive } \\
(7) \\
\end{array}$ & $\begin{array}{l}\text { High } \\
(8) \\
\end{array}$ & $\begin{array}{c}\text { Low } \\
(9) \\
\end{array}$ \\
\hline Share of immigration $*$ formal education & $\begin{array}{r}-0.00909 \\
(0.00953)\end{array}$ & $\begin{array}{c}-0.0105 \\
(0.00881)\end{array}$ & $\begin{array}{r}-0.00632 \\
(0.00694)\end{array}$ & $\begin{array}{c}0.00163 \\
(0.00897)\end{array}$ & $\begin{array}{l}-0.00951 \\
(0.00791)\end{array}$ & $\begin{array}{c}-0.0111^{*} \\
(0.00627)\end{array}$ & $\begin{array}{c}-0.000837 \\
(0.0132)\end{array}$ & $\begin{array}{r}-0.0133 \\
(0.0110)\end{array}$ & $\begin{array}{l}-0.00548 \\
(0.0307)\end{array}$ \\
\hline Birthplace diversity (immigrants) $*$ formal education & $\begin{array}{c}0.0329 * * * \\
(0.0122)\end{array}$ & $\begin{array}{c}0.0287 * * \\
(0.0120)\end{array}$ & $\begin{array}{c}0.0100 \\
(0.00711)\end{array}$ & $\begin{array}{c}0.0366 * * * \\
(0.0133)\end{array}$ & $\begin{array}{c}-0.00151 \\
(0.00896)\end{array}$ & $\begin{array}{l}-0.00465 \\
(0.0107)\end{array}$ & $\begin{array}{l}0.0227^{*} \\
(0.0121)\end{array}$ & $\begin{array}{c}0.0103 \\
(0.0163)\end{array}$ & $\begin{array}{c}-0.00689 \\
(0.0201)\end{array}$ \\
\hline Skill ratio $*$ formal education & $\begin{array}{c}0.0380 * * * \\
(0.0132)\end{array}$ & $\begin{array}{c}0.0351 * * * \\
(0.0134)\end{array}$ & $\begin{array}{l}0.0260 * * * \\
(0.00933)\end{array}$ & $\begin{array}{c}-0.0103 \\
(0.0150)\end{array}$ & $\begin{array}{c}0.0382 * * * \\
(0.00914)\end{array}$ & $\begin{array}{c}0.0258 * * \\
(0.0103)\end{array}$ & $\begin{array}{l}0.0301 * * \\
(0.0124)\end{array}$ & $\begin{array}{c}0.0440^{* *} \\
(0.0214)\end{array}$ & $\begin{array}{c}-0.0466 * * * \\
(0.0179)\end{array}$ \\
\hline Formal education (educational attainment, 5 levels) & $\begin{array}{c}-0.105^{* * *} \\
(0.0102)\end{array}$ & $\begin{array}{c}-0.0644 * * *- \\
(0.00774)\end{array}$ & $\begin{array}{c}-0.0633^{* * *} \\
(0.00781)\end{array}$ & $\begin{array}{c}-0.0586^{* * *}- \\
(0.0113)\end{array}$ & $\begin{array}{c}-0.0760 * * * \\
(0.00909)\end{array}$ & $\begin{array}{c}-0.0679 * * * \\
(0.00877)\end{array}$ & $\begin{array}{c}-0.0595 * * * \\
(0.0116)\end{array}$ & & \\
\hline Formal education (if post secondary) & & & & & & & & $\begin{array}{c}-0.130 * * * \\
(0.0172)\end{array}$ & \\
\hline Formal education (if up to lower secondary) & & & & & & & & & $\begin{array}{c}0.105^{* * *} \\
(0.0195)\end{array}$ \\
\hline Fixed effects & & & & & & & & & \\
\hline $\begin{array}{l}\text { Country-Year } \\
\text { Occupation (ISCO level-1) }\end{array}$ & $\mathrm{x}$ & $\begin{array}{l}\mathrm{x} \\
\mathrm{x}\end{array}$ & $\mathrm{x}$ & $\mathrm{x}$ & $\mathrm{x}$ & $\mathrm{x}$ & $\mathrm{x}$ & $\mathrm{x}$ & $\mathrm{x}$ \\
\hline Country-Occupation (ISCO level-1) & & & $\mathrm{x}$ & $\mathrm{x}$ & $\mathrm{x}$ & $\mathrm{x}$ & $\mathrm{x}$ & $\mathrm{x}$ & $\mathrm{x}$ \\
\hline Observations & 92,847 & 92,847 & 92,775 & 24,392 & 68,259 & 57,393 & 35,238 & 92,775 & 92,775 \\
\hline Pseudo R2 & 0.112 & 0.116 & 0.122 & 0.101 & 0.135 & 0.129 & 0.120 & 0.121 & 0.121 \\
\hline
\end{tabular}


Table 4: Preferences for redistribution - labor market skill (occupational skill intensities)

Table 4: Preferences for redistribution - heterogeneity in occupational skills / task skill intensity

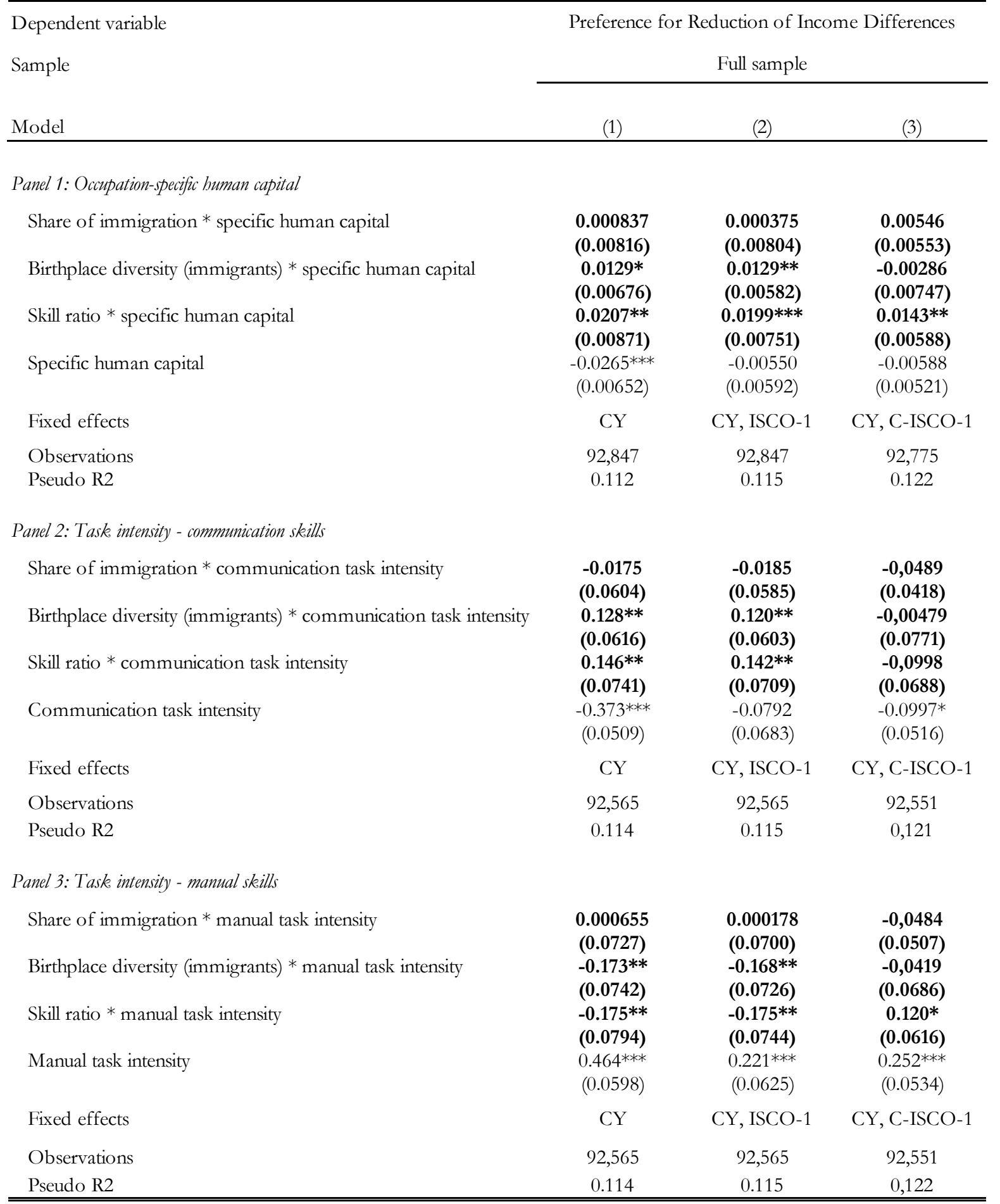

Fixed effects: Country-year (CY), occupation (ISCO-1) and/or country-occupation (C-ISCO-1). Occupation-specific human capital based on self-assessment of job relevant skills (based on ESS). Task intensities based on O*Net database following Peri \& Sparber (2009). Model includes full vector of individual level controls. Sample excludes non-native citizens. Share, diversity and skill ratio $(\log )$ standardized with zero mean and standard deviation of 1 . Standard errors corrected for heteroskedasticity and clustering of the residuals at the country level. ${ }^{* *},{ }^{* *},{ }^{*}$ indicate statistical significance at the $1 \%, 5 \%$ and $10 \%$ level, respectively. 


\section{Table 5: Preferences for redistribution - simulation exercise}

Table 5: Preferences for redistribution - native citizen and immigration by genetic distance and income at oris

\section{Dimension 1: Genetic distance}

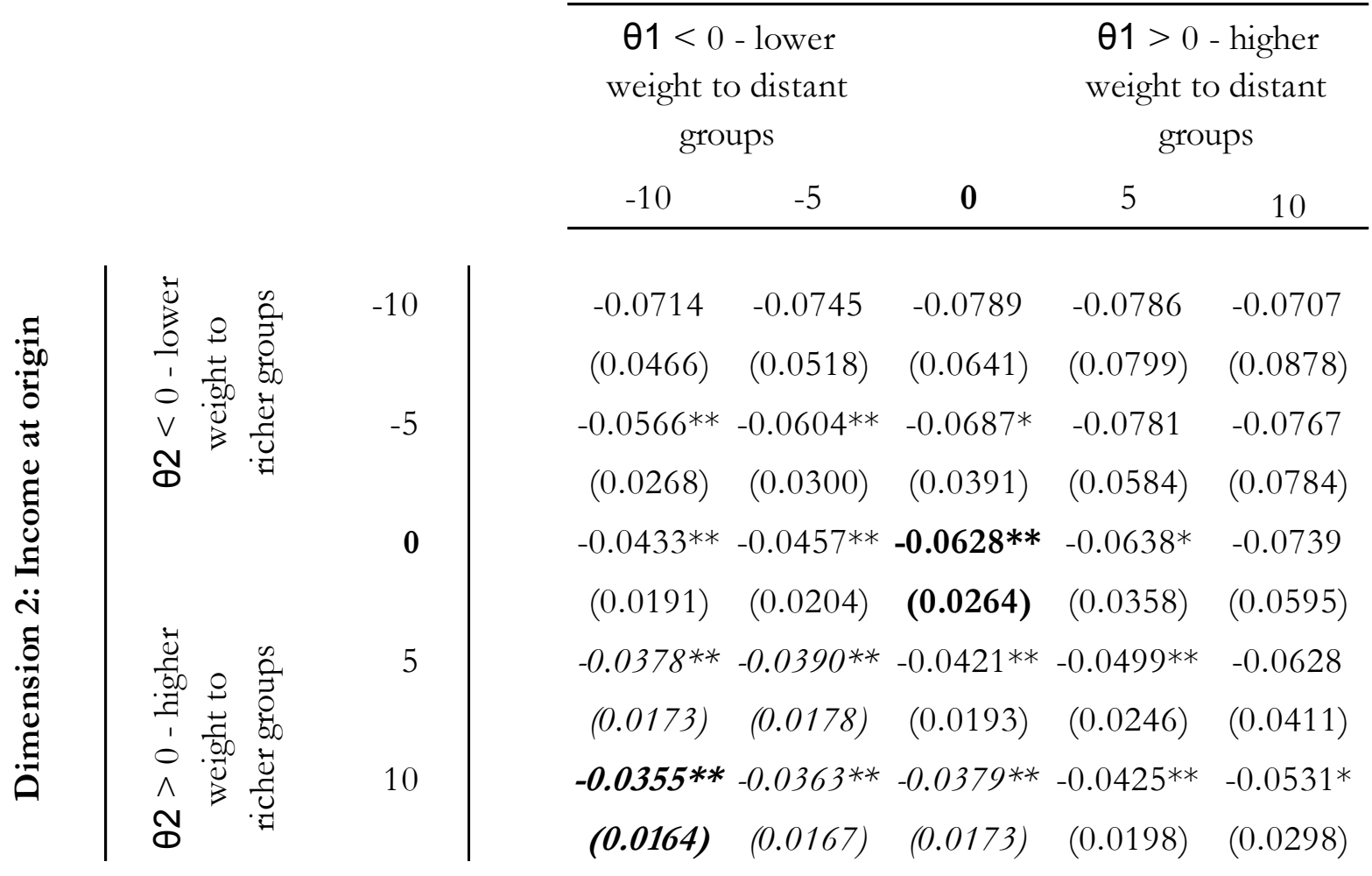

Table shows probit coefficients on full model including country-year fixed effects based on Table 2 (model 1). Coefficients in italics are significantly different from the baseline coefficient $(\theta 1=0$, $\theta 2=0)$ at the $10 \%$ level. Share, diversity and skill ratio $(\log )$ standardized with zero mean and standard deviation of 1. Models include full range of individual level controls (not reported). Standard errors corrected for heteroskedasticity and clustering of the residuals at the country level. $* * *, * *, *$ indicate statistical significance at the $1 \%, 5 \%$ and $10 \%$ level, respectively. 
Table 6: Robustness to restricted samples

Table 6a: Preferences for redistribution - native citizens

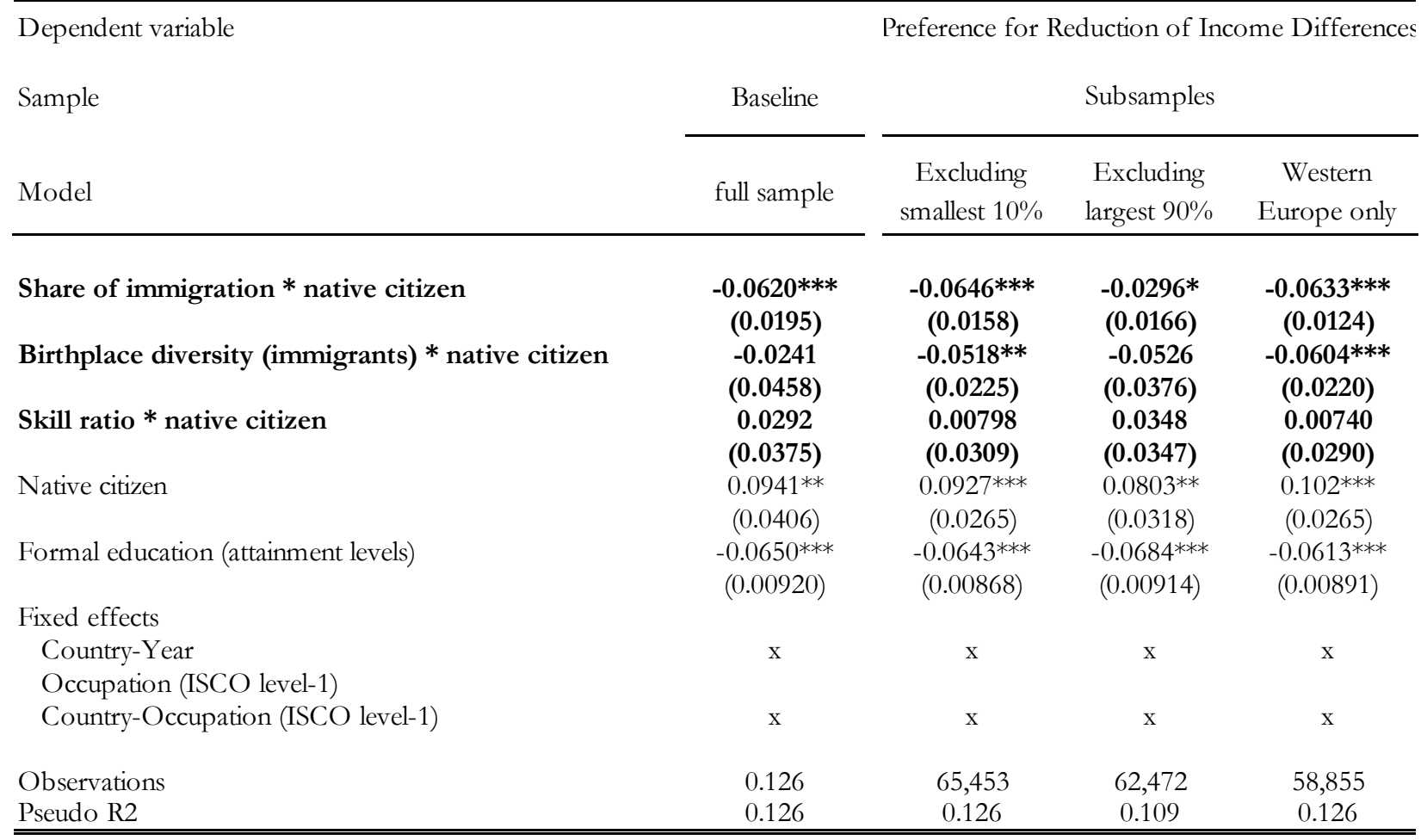

Table 6b: Preferences for redistribution - heterogeneity in education/skills

Dependent variable

Sample

Model
Baseline

full sample

Share of immigration $*$ formal education

Birthplace diversity (immigrants) * formal education

Skill ratio $*$ formal education

Formal education (attainment levels)

Fixed effects

$$
\begin{aligned}
& \text { Country-Year } \\
& \text { Occupation (ISCO level-1) } \\
& \text { Country-Occupation (ISCO level-1) }
\end{aligned}
$$

Observations

Pseudo R2
Preference for Reduction of Income Differences

Subsamples

\begin{tabular}{ccc}
\hline $\begin{array}{c}\text { Excluding } \\
\text { smallest } 10 \%\end{array}$ & $\begin{array}{c}\text { Excluding } \\
\text { largest } 90 \%\end{array}$ & $\begin{array}{c}\text { Western } \\
\text { Europe only }\end{array}$ \\
\hline & & \\
$\mathbf{- 0 . 0 0 4 3 8}$ & $\mathbf{0 . 0 0 3 1 7}$ & $\mathbf{- 0 . 0 1 4 7 * *}$ \\
$\mathbf{( 0 . 0 0 6 9 2 )}$ & $\mathbf{( 0 . 0 0 9 9 4 )}$ & $\mathbf{( 0 . 0 0 7 1 8 )}$ \\
$\mathbf{0 . 0 1 6 0 * * *}$ & $\mathbf{0 . 0 0 6 9 7}$ & $\mathbf{0 . 0 2 0 7 * * *}$ \\
$\mathbf{( 0 . 0 0 4 6 7 )}$ & $\mathbf{( 0 . 0 0 5 7 3 )}$ & $\mathbf{( 0 . 0 0 3 7 6 )}$ \\
$\mathbf{0 . 0 1 9 1 * *}$ & $\mathbf{0 . 0 2 0 6 * * *}$ & $\mathbf{0 . 0 1 5 3} * *$ \\
$\mathbf{( 0 . 0 0 8 3 7 )}$ & $\mathbf{( 0 . 0 0 7 4 8 )}$ & $\mathbf{( 0 . 0 0 6 4 5 )}$ \\
$-0.0652^{* * *}$ & $-0.0697 * * *$ & $-0.0637^{* * *}$ \\
$(0.00632)$ & $(0.00726)$ & $(0.00571)$ \\
& & \\
x & $\mathrm{x}$ & $\mathrm{x}$ \\
$\mathrm{x}$ & $\mathrm{x}$ & $\mathrm{x}$ \\
62,606 & 60,008 & 55,818 \\
0.128 & 0.111 & 0.129 \\
\hline
\end{tabular}

Models include a full vector of individual level controls. Share, diversity and skill ratio (log) standardized with zero mean and standard deviation of 1 . Standard errors corrected for heteroskedasticity and clustering of the residuals at the country level. $* * *, * *, *$ indicate statistical significance at the $1 \%, 5 \%$ and $10 \%$ level, respectively. 


\section{Table 7: Gravity model}

\section{Panel A: Gravity model}

Table 7: Gravity model for bilateral migration

\begin{tabular}{lccc}
\hline \hline Dependent variable & \multicolumn{3}{c}{ Bilateral migration, ISCO-1 level from country i to country j } \\
\cline { 2 - 4 } Model & all & skilled & unskilled \\
\cline { 2 - 4 } Specification & $(1)$ & $(2)$ & $(3)$ \\
\hline \multirow{2}{*}{ Native labor force population } & $2.80 \mathrm{e}-07^{* * *}$ & $6.97 \mathrm{e}-07^{* * *}$ & $2.98 \mathrm{e}-07^{* * *}$ \\
& $(3.21 \mathrm{e}-08)$ & $(1.47 \mathrm{e}-07)$ & $(3.55 \mathrm{e}-08)$ \\
Bilateral distance & $-7.33 \mathrm{e}-05$ & $-1.26 \mathrm{e}-05$ & -0.000104 \\
& $(5.52 \mathrm{e}-05)$ & $(3.09 \mathrm{e}-05)$ & $(6.48 \mathrm{e}-05)$ \\
Colonial relationship & $1.457^{* * *}$ & $1.525^{* * *}$ & $1.516^{* * *}$ \\
& $(0.272)$ & $(0.381)$ & $(0.311)$ \\
Common official language & $1.108^{* * *}$ & $1.300^{* * *}$ & $0.996^{* * *}$ \\
Border contiguity & $(0.203)$ & $(0.257)$ & $(0.219)$ \\
& $1.431^{* * *}$ & $1.081^{* * *}$ & $1.497^{* * *}$ \\
Observations & $(0.231)$ & $(0.183)$ & $(0.291)$ \\
Pseudo R2 & & & 72,580 \\
\hline \hline
\end{tabular}

Model includes origin country fixed effects. Standard errors corrected for heteroskedasticity and clustering of the residuals at the destination country level. ${ }^{* * *},{ }^{* *}, *$ indicate statistical significance at the $1 \%, 5 \%$ and $10 \%$ level, respectively.

Panel B: Gravity model results - fit (all skill levels)

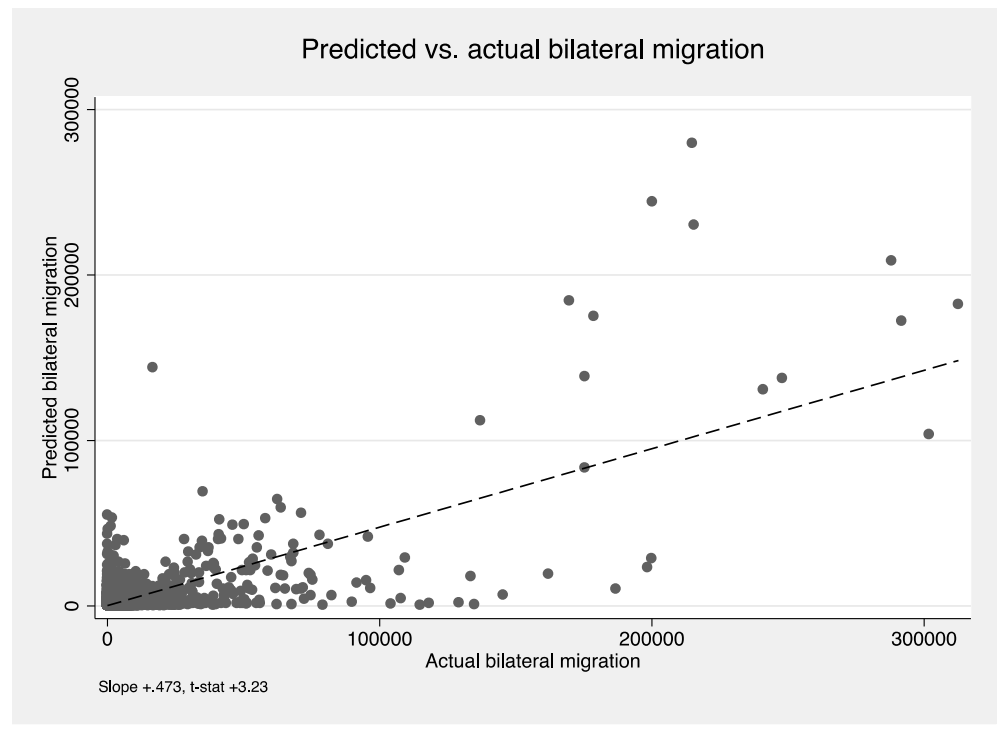


Table 8: 2SLS results

Table 8: Preferences for redistribution - IV results (two stage least squares)

\begin{tabular}{|c|c|c|c|c|c|}
\hline $\begin{array}{l}\text { Dependent variable } \\
\text { Sample }\end{array}$ & Preference for Re & uction of Income I & $\begin{array}{l}\text { ifferences }(5=" a s \\
\text { Full sample }\end{array}$ & ree strongly", 1=" & lisagree strongly") \\
\hline Type of interaction variable (A) & native citizen & formal education & $\begin{array}{c}\text { job specific } \\
\text { human capital }\end{array}$ & $\begin{array}{l}\text { communication } \\
\text { task intensity }\end{array}$ & $\begin{array}{l}\text { manual task } \\
\text { intensity }\end{array}$ \\
\hline Model & (1) & (2) & (3) & (4) & (5) \\
\hline Share of immigration * variable (A) & $\begin{array}{c}-0.0600 * * * \\
(0.0163)\end{array}$ & $\begin{array}{l}-0.00685 \\
(0.0123)\end{array}$ & $\begin{array}{l}-0.00565 \\
(0.00798)\end{array}$ & $\begin{array}{l}-0.0238 \\
(0.0667)\end{array}$ & $\begin{array}{l}-0.00389 \\
(0.0539)\end{array}$ \\
\hline Birthplace diversity (immigrants) $*$ variable (A) & $\begin{array}{l}-0.0761 * * \\
(0.0377)\end{array}$ & $\begin{array}{c}0.0197 \\
(0.0134)\end{array}$ & $\begin{array}{c}0.0178 \\
(0.0130)\end{array}$ & $\begin{array}{r}-0.0105 \\
(0.0747)\end{array}$ & $\begin{array}{c}-0.0603 \\
(0.0922)\end{array}$ \\
\hline Skill ratio $*$ variable $(\mathrm{A})$ & $\begin{array}{r}0.00174 \\
(0.0453)\end{array}$ & $\begin{array}{c}0.0456^{* * *} \\
(0.0155)\end{array}$ & $\begin{array}{l}0.0164 * * * \\
(0.00572)\end{array}$ & $\begin{array}{c}0.000576 \\
(0.0758)\end{array}$ & $\begin{array}{c}0.0260 \\
(0.0837)\end{array}$ \\
\hline Native citizen & $\begin{array}{c}0.0772 * * * \\
(0.0233)\end{array}$ & & & & \\
\hline Formal education (educational attainment, 5 levels) & $\begin{array}{c}-0.0471 * * * \\
(0.00768)\end{array}$ & $\begin{array}{c}-0.0480 * * * \\
(0.00704)\end{array}$ & & & \\
\hline Specific human capital & & & $\begin{array}{c}-0.0115^{* *} \\
(0.00529)\end{array}$ & & \\
\hline Communication task intensity & & & & $\begin{array}{c}-0.118^{* * *} \\
(0.0448)\end{array}$ & \\
\hline Manual task intensity & & & & & $\begin{array}{c}0.242^{* * *} \\
(0.0473)\end{array}$ \\
\hline Fixed effects & CY, C-ISCO-1 & CY, C-ISCO-1 & CY, C-ISCO-1 & CY, C-ISCO-1 & CY, C-ISCO-1 \\
\hline Angrist-Pischke F-Test on share & 33,03 & 4.50 & 5,37 & 8.80 & 8,96 \\
\hline Angrist-Pischke F-Test on diversity of immigration & 21,53 & 4,41 & 2,39 & 2,44 & 2,29 \\
\hline Angrist-Pischke F-Test on skill ratio & 8,35 & 23,91 & 16,8 & 18,69 & 19,83 \\
\hline F-Test on instruments & 17.15 & 58.45 & 21.18 & 20.32 & 21.83 \\
\hline Observations & 95,187 & 91,162 & 91,162 & 90,990 & 90,990 \\
\hline R2 & 0.048 & 0.049 & 0.047 & 0.047 & 0.048 \\
\hline
\end{tabular}

Share immigration, diversity and skill ratio instrumented using PPML-based gravity model. Share, diversity and skill ratio (log) standardized with zero mean and standard deviation of 1 . Standard errors corrected for heteroskedasticity and clustering of the residuals at the country level. ***, **, * indicate statistical significance at the $1 \%, 5 \%$ and $10 \%$ level, respectively. 


\section{APPENDIX}

Table A1: Share of immigration, diversity and (slog) skill ratio

\begin{tabular}{|c|c|c|c|}
\hline & $\begin{array}{c}\text { Share } \\
\text { of immigrants }\end{array}$ & $\begin{array}{c}\text { Diversity } \\
\text { of immigrants }\end{array}$ & $\begin{array}{c}\text { Log Skill Ratio of } \\
\text { Immigrants to } \\
\text { Natives }\end{array}$ \\
\hline SAMPLE AVERAGE & 0,11 & 0,80 & $-0,58$ \\
\hline \multicolumn{4}{|l|}{ BY COUNTRY } \\
\hline AUT & 0,14 & 0,92 & $-0,67$ \\
\hline BEL & 0,12 & 0,93 & $-0,70$ \\
\hline BGR & 0,00 & 0,83 & $-0,41$ \\
\hline $\mathrm{CHE}$ & 0,25 & 0,93 & $-0,57$ \\
\hline CZE & 0,05 & 0,58 & $-0,59$ \\
\hline $\mathrm{DEU}$ & 0,12 & 0,90 & $-0,83$ \\
\hline DNK & 0,07 & 0,96 & $-0,60$ \\
\hline ESP & 0,05 & 0,94 & $-0,62$ \\
\hline EST & 0,22 & 0,42 & $-0,54$ \\
\hline FIN & 0,03 & 0,87 & $-0,81$ \\
\hline FRA & 0,12 & 0,91 & $-0,66$ \\
\hline GBR & 0,09 & 0,96 & $-0,46$ \\
\hline GRC & 0,11 & 0,86 & $-0,63$ \\
\hline HRV & 0,15 & 0,40 & $-0,66$ \\
\hline HUN & 0,03 & 0,72 & $-0,43$ \\
\hline IRL & 0,11 & 0,61 & $-0,44$ \\
\hline ISR & 0,40 & 0,93 & $-0,49$ \\
\hline ITA & 0,04 & 0,96 & $-0,51$ \\
\hline LUX & 0,37 & 0,86 & $-0,46$ \\
\hline NLD & 0,11 & 0,90 & $-0,68$ \\
\hline POL & 0,02 & 0,77 & $-0,63$ \\
\hline PRT & 0,07 & 0,87 & $-0,34$ \\
\hline RUS & 0,10 & 0,84 & $-0,57$ \\
\hline SVK & 0,03 & 0,57 & $-0,52$ \\
\hline SVN & 0,10 & 0,72 & $-0,78$ \\
\hline SWE & 0,14 & 0,94 & $-0,66$ \\
\hline TUR & 0,02 & 0,78 & $-0,37$ \\
\hline UKR & 0,12 & 0,49 & $-0,56$ \\
\hline
\end{tabular}


Table A2: Correlations

Bilateral correlations of country averages (weighted), $n=28$

(1)

\begin{tabular}{lcccc}
\hline \hline (1) Preference for Redistribution & 1,00 & & & \\
(2) Share of Immigration & $-0,16$ & 1,00 & & \\
(3) Birthplace Diversity & $-0,19$ & 0,05 & 1,00 & \\
(4) Relative Skill Ratio (log) & 0,28 & 0,30 & 0,02 & 0,10 \\
\hline
\end{tabular}

(4)

$$
\text { . }
$$

.

Table A3: Summary statistics

\begin{tabular}{|c|c|c|c|c|c|}
\hline Variable & Obs & Mean & Std. Dev. & Min & $\operatorname{Max}$ \\
\hline Share of immigration & 28 & 0,11 & 0,10 & 0,00 & 0,40 \\
\hline Diversity of immigrants & 28 & 0,80 & 0,17 & 0,40 & 0,96 \\
\hline Skill Ratio (log) & 28 & $-0,58$ & 0,13 & $-0,83$ & $-0,34$ \\
\hline Share of immigration, ISCO-1 digit level & 274 & 0,10 & 0,11 & 0,00 & 0,64 \\
\hline Diversity of immigrants, ISCO-1 digit level & 274 & 0,83 & 0,17 & 0,00 & 0,99 \\
\hline Skill Ratio (log), ISCO-1 digit level & 273 & $-0,52$ & 0,20 & $-1,65$ & $-0,05$ \\
\hline Preference for redistribution of income difference & 96855 & 3,81 & 1,07 & 1 & 5 \\
\hline Preference for redistribution, dichotomous variab & 96958 & 0,70 & 0,46 & 0 & 1 \\
\hline Native citizen & 96958 & 0,96 & 0,20 & 0 & 1 \\
\hline Formal education (attainment levels) & 96958 & 3,43 & 1,26 & 1 & 5 \\
\hline Formal education (up to lower secondary) & 96958 & 0,20 & 0,40 & 0 & 1 \\
\hline Formal education (above secondary) & 96958 & 0,38 & 0,48 & 0 & 1 \\
\hline Job specific human capital (log) & 96958 & 0,10 & 1,38 & -8 & 4 \\
\hline Task intensity, communication skills & 96672 & 0,47 & 0,23 & 0 & 1 \\
\hline Task intensity, manual skills & 96672 & 0,54 & 0,18 & 0 & 1 \\
\hline Gender & 96958 & 0,50 & 0,50 & 0 & 1 \\
\hline Age & 96958 & 41,38 & 11,61 & 18 & 64 \\
\hline Income (deciles) & 96958 & 5,99 & 2,55 & 1 & 10 \\
\hline Political orientation (left-right spectrum) & 96958 & 5,08 & 2,11 & 0 & 10 \\
\hline Rural area & 96958 & 0,36 & 0,48 & 0 & 1 \\
\hline Self-employment (exkl. pensions) & 96958 & 0,09 & 0,29 & 0 & 1 \\
\hline Partner currently unemployed & 96958 & 0,04 & 0,19 & 0 & 1 \\
\hline Ever unemployed for more than three months & 96925 & 0,33 & 0,47 & 0 & 1 \\
\hline Household size & 96958 & 3,25 & 1,42 & 1 & 15 \\
\hline Member of trade union (current or past) & 96958 & 0,45 & 0,50 & 0 & 1 \\
\hline Legal marital status & 96958 & 0,63 & 0,48 & 0 & 1 \\
\hline Public sector occupation & 96958 & 0,25 & 0,44 & 0 & 1 \\
\hline Positive/ negative view on immigration & 96958 & 0,62 & 0,49 & 0 & 1 \\
\hline Religious belief & 96958 & 0,59 & 0,49 & 0 & 1 \\
\hline
\end{tabular}


Table A4: Sources and definitions

\begin{tabular}{|c|c|c|}
\hline Variable & Source & Definition \\
\hline Share of immigration & OECD $(2000)$ & sum of immigrants / total population, labor force age $15+$ \\
\hline Diversity of immigrants & based on OECD (2000) & Herfindahl index of immigrant group shares, labor force age $15+$ \\
\hline Skill Ratio (log) & based on OECD (2000) & $\begin{array}{l}\text { log of skilled/unskilled immigrants / skilled/unskilled natives, } \\
\text { labor force age } 15+\end{array}$ \\
\hline Share of immigration, ISCO-1 digit level & OECD (2000) & sum of immigrants / total population, labor force age $15+$ \\
\hline Diversity of immigrants, ISCO-1 digit level & based on OECD (2000) & Herfindahl index of immigrant group shares, labor force age $15+$ \\
\hline Skill Ratio (log), ISCO-1 digit level & based on OECD (2000) & $\begin{array}{l}\text { log of skilled/unskilled immigrants / skilled/unskilled natives, } \\
\text { labor force age } 15+\end{array}$ \\
\hline Preference for redistribution of income differences & ESS & see Table $1 \mathrm{a} / \mathrm{b}$ for details \\
\hline Preference for redistribution, dichotomous variable & ESS & see Table $1 \mathrm{a} / \mathrm{b}$ for details \\
\hline Native citizen & ESS & $0=$ not native citizen, $1=$ native citizen \\
\hline Formal education (attainment levels) & ESS & $1=$ primary education, $5=$ completed tertiary education \\
\hline Formal education - low (up to lower secondary) & ESS & $0=$ above, $1=$ up to and including lower secondary education \\
\hline Formal education - high (above secondary) & ESS & $\begin{array}{l}0=\text { up to and including } 1=\text { above completed secondary } \\
\text { education }\end{array}$ \\
\hline Job specific human capital (log) & based on ESS, wave 2 and 5 & $\begin{array}{l}\text { based on ESS question "If somebody with the right education } \\
\text { and qualifications replaced you in your job, how long would it } \\
\text { take for them to learn to do the job reasonable well?", } \\
\text { linearization to years following Ortega and Polavieja, } 2012\end{array}$ \\
\hline Task intensity, communication skills & based on $\mathrm{O}^{*} \mathrm{NET}(2010)$ & $\begin{array}{l}\text { matched to ISCO occupations using crosswalk provided Centre } \\
\text { for Longitudinal Studies, University of London, definition }\end{array}$ \\
\hline Task intensity, manual skills & based on $\mathrm{O}^{*} \mathrm{NET}(2010)$ & analogue to Peri and Sparber, 2009 \\
\hline Gender & ESS & $0=$ female, $1=$ male \\
\hline Age & ESS & in years \\
\hline Income (deciles) & ESS & in country-specific income deciles \\
\hline Political orientation (left-right spectrum) & ESS & self identified. $0=$ left, $10=$ right \\
\hline Rural area & ESS & $0=$ if city, suburb or town, $1=$ if country village or countryside \\
\hline Self-employment (exkl. pensions) & ESS & $1=$ if self-employed (not family business, not pensioneer) \\
\hline Partner currently unemployed & ESS & $1=$ partner currently unemployed \\
\hline Ever unemployed for more than three months & ESS & $1=$ if ever unemployed at least 3 months \\
\hline Household size & ESS & in number of household members \\
\hline Member of trade union (current or past) & ESS & $1=$ ever been member of trade union \\
\hline Legal marital status & ESS & $\begin{array}{l}1 \text { = if currently legaly married, in civil union or pact solidarité } \\
\text { (France) }\end{array}$ \\
\hline Religious belief & ESS & $1=$ if holding some religious belief \\
\hline Public sector occupation & based on ESS & $\begin{array}{l}1=\text { if occupation "public administration, defense or compulsory } \\
\text { social service, education or health/social work" }\end{array}$ \\
\hline Attitude towards immigrants (dummy) & based on ESS & $\begin{array}{l}1 \text { = if answer to question "Immigrants make country worse } \\
\text { (better) place to live" (scale 0-10) leaning towards "worse" } \\
\text { (answers } 0-5 \text { ) }\end{array}$ \\
\hline
\end{tabular}




\section{Table A 5: Reduced form results}

Appendix 5: Preferences for redistribution - reduced form results

\begin{tabular}{|c|c|c|c|}
\hline \multirow[t]{3}{*}{ Dependent variable } & \multicolumn{3}{|c|}{ Preference for Reduction of Income Differ } \\
\hline & Full sample & \multicolumn{2}{|c|}{$\begin{array}{l}\text { Perceived effects } \\
\text { of immigration }\end{array}$} \\
\hline & & negative & positive \\
\hline Model & $(1)$ & $(2)$ & (3) \\
\hline \multicolumn{4}{|l|}{ Panel 1: Natives vs. non-natives } \\
\hline Share of immigration $*$ native citizen & $\begin{array}{c}-0.0308 * * \\
(0.0156)\end{array}$ & $\begin{array}{c}-0.0494 * * * \\
(0.0181)\end{array}$ & $\begin{array}{l}-0.0152 \\
(0.0209)\end{array}$ \\
\hline Birthplace diversity (immigrants) $*$ native citizen & $\begin{array}{l}-0.0523 \\
(0.0401)\end{array}$ & $\begin{array}{l}-0.0856 * \\
(0.0495)\end{array}$ & $\begin{array}{l}-0.00901 \\
(0.0356)\end{array}$ \\
\hline Skill ratio $*$ native citizen & $\begin{array}{l}-0.0106 \\
(0.0320)\end{array}$ & $\begin{array}{l}-0.0581 \\
(0.0436)\end{array}$ & $\begin{array}{c}0.0128 \\
(0.0525)\end{array}$ \\
\hline Native citizen & $\begin{array}{c}0.0730^{* * *} \\
(0.0278)\end{array}$ & $\begin{array}{c}0.159 * * * \\
(0.0479)\end{array}$ & $\begin{array}{c}0.0213 \\
(0.0280)\end{array}$ \\
\hline Fixed effects & CY, C-ISCO-1 & CY, C-ISCO-1 & CY, C-ISCO-1 \\
\hline Observations & 95,269 & 58,119 & 37,004 \\
\hline Pseudo R2 & 0.116 & 0.124 & 0.114 \\
\hline
\end{tabular}

Panel 2: Heterogeneity in education/ skills

\begin{tabular}{|c|c|c|c|c|}
\hline $\begin{array}{l}\text { Type of education variable } \\
\text { Model }\end{array}$ & $\begin{array}{l}\text { formal education } \\
\text { (A) }\end{array}$ & $\begin{array}{l}\text { job specific } \\
\text { human capital } \\
\text { (B) }\end{array}$ & $\begin{array}{l}\text { communication } \\
\text { task intensity } \\
\text { (C) }\end{array}$ & $\begin{array}{l}\text { manual task } \\
\text { intensity } \\
\text { (D) }\end{array}$ \\
\hline Share of immigration $*$ education & $\begin{array}{c}-0.0144 * * \\
(0.00675)\end{array}$ & $\begin{array}{c}-0.00404 \\
(0.00372)\end{array}$ & $\begin{array}{c}-0.00837 \\
(0.0492)\end{array}$ & $\begin{array}{c}0.0486 \\
(0.0465)\end{array}$ \\
\hline Birthplace diversity (immigrants) $*$ education & $\begin{array}{c}0.0161 * * * \\
(0.00564)\end{array}$ & $\begin{array}{c}0.0124 * * * \\
(0.00424)\end{array}$ & $\begin{array}{l}-0.0215 \\
(0.0404)\end{array}$ & $\begin{array}{l}-0.0627 \\
(0.0592)\end{array}$ \\
\hline Skill ratio $*$ education & $\begin{array}{c}0.0203 * * \\
(0.00959)\end{array}$ & $\begin{array}{c}0.0184 * * * \\
(0.00452)\end{array}$ & $\begin{array}{c}-0.0180 \\
(0.0507)\end{array}$ & $\begin{array}{c}0.0514 \\
(0.0951)\end{array}$ \\
\hline Formal education (educational attainment, 5 levels) & $\begin{array}{c}-0.0589 * * * \\
(0.00808)\end{array}$ & & & \\
\hline Specific human capital & & $\begin{array}{l}-0.00548 \\
(0.00510)\end{array}$ & & \\
\hline Communication task intensity & & & $\begin{array}{c}-0.116^{* *} \\
(0.0558)\end{array}$ & \\
\hline Manual task intensity & & & & $\begin{array}{c}0.254^{* * *} \\
(0.0606)\end{array}$ \\
\hline Fixed effects & CY, C-ISCO-1 & CY, C-ISCO-1 & CY, C-ISCO-1 & CY, C-ISCO-1 \\
\hline Observations & 91,228 & 91,228 & 91,063 & 91,063 \\
\hline Pseudo R2 & 0.119 & 0.117 & 0.117 & 0.117 \\
\hline
\end{tabular}

Share immigration, diversity and skill ratio predicted using PPML gravity model. Share, diversity and skill ratio (log) standardized with zero mean and standard deviation of 1 . Standard errors corrected for heteroskedasticity and clustering of the residuals at the country level. ***, **, * indicate statistical significance at the $1 \%, 5 \%$ and $10 \%$ level, respectively. 